\title{
LO MÚLTIPLE EN ALONSO CANO ESCULTOR
}

\author{
POR \\ DOMINGO SÁNCHEZ-MESA MARTÍN \\ Universidad de Granada
}

\begin{abstract}
In the following study, Alonso Cano's polifacetic activity is approached from the point of view of his work as sculptor, focusing on the manyfold connections among his ideas on plastic art which are displayed in his sculptures, paintings, architecture and drawings. Instead of providing a detailed account of the differences between Cano as sculptor and Cano as painter or architect, the author aims to show what is common in his creations, considering these as «multiple» though being the outcome of one individual's concept and making. Besides that, new ascriptions corresponding to his Granadian period are brought to come to a final proposal for a catalogue of Cano's sculptoric work.
\end{abstract}

Analizada globalmente la obra total de Alonso Cano, se hace evidente que el concepto que el artista tuvo y practicó de la forma plástica revela bien a las claras una vocación fundamentalmente de escultor, sin que en nada se contradiga su apasionamiento y aguda capacidad para el color y para la creación de los espacios pictóricos y arquitectónicos. Pero, al final, pienso que Cano ve siempre la forma, libre y con plenitud, como volumen en redondo. Curiosamente, es bien significativo - por lo que hasta hoy se conoce-, que no practicara el relieve escultórico, modalidad de mayor naturaleza pictórica dentro del propio lenguaje escultórico.

Esta evidencia ha hecho que se venga repitiendo, desde Ceán Bermúdez, que la verdadera fama de Cano descansa en su escultura, afirmación no compartida por otros historiadores, que dan a su condición y visión de pintor la primacía sobre sus actividades escultóricas, como es el caso de Camón Aznar, que afirma que su inspiración es más bien pictórica que plástica '. Sin embargo, para Wethey esta preferencia valorativa sobre lo escultórico supone una actitud que se explica, en parte por la deplorable costumbre de repetir opiniones conocidas, como si fueran verdades demostradas, y en parte como consecuencia de un estudio insuficiente de la obra pictórica del artista ${ }^{2}$.

Sin compartir totalmente este planteamiento del prestigioso investigador norteamericano, que, por otra parte, deja en su conocida monografía sobre el artista pruebas suficientes de su mayor preferencia personal por la pintura que por la escultura policromada, es constatable que la producción de Cano escultor es menor que la de pintor ${ }^{3}$. Pero, en el sentido en el que acep-

1 Camón Aznar, J., «Los estilos de Alonso Cano», en Centenario de Alonso Cano en Granada. Estudios. Granada, 1969, p. 19.

2 Wethey, H., Alonso Cano, escultor, pintor y arquitecto. Madrid, Alianza, 1983, p. 17.

3 Urrea Fernández, J., «Alonso Cano, escultor: su catálogo», en Figuras e imágenes para el Barroco. Madrid, Argentaria, 1999 , p. 237. En resumen se anota que para Wethey el catálogo de esculturas de Cano alcanza el número de 21 ; Láza- 
tamos las razones de la afirmación de Ceán es en el de que nos hace apreciar en la propia actividad de Cano como pintor, arquitecto y dibujante, una constante presencia de su experiencia práctica con la escultura, con los propios valores escultóricos, también resaltados y dichos con su rica y excelente paleta o con sus dibujos abocetados en planos de luces y sombras.

En síntesis, se puede afirmar que Cano esculpe y talla pintando y dibujando $-\mathrm{y}$ viceversa-, sin que esto reste lo más mínimo a sus obras los valores que le son propias a la naturaleza de sus respectivos lenguajes plásticos. Se trata, pues, de insistir una vez más en uno de los rasgos más sobresalientes del artista —nacido hace ahora 400 años-, como es su polifacética actividad, plasmada tanto en el campo de la pintura y la escultura, como en el de la arquitectura y el dibujo.

Generalmente, esta circunstancia, tan conocida y comentada en las visiones de conjunto de nuestro arte barroco, se hace ya tópica al referirse específicamente a Cano como artista de condición universal, al modo de los grandes maestros del Renacimiento, que practicaban las artes en la mayoría de sus especialidades, acompañando a la dimensión práctica también la teórica y propiamente de investigación plástica. De tantos casos como brevemente podríamos recordar a mero titulo ilustrativo, tomemos el texto de aquella carta que el gran Leonardo dirigía a Ludovico el Moro, Señor de Milán, al ofrecerse para su servicio cuando contaba 30 años; caso y personaje que en tantas ocasiones se pondría como ejemplo digno de imitación a los artistas posteriores de lo que tendría que ser o a lo que tendría que aspirar todo creador que se preciara con dignidad y orgullo de ello:

«... sé igualmente realizar escultura en mármol, bronce o barro, y también pintar, en lo que mi obra puede compararse con la de aquellos otros artistas sea quien sea...»

Pero aún y a pesar de esta polifacética actividad de Cano en sus casi 66 años de existencia y su ajetreado vivir, primero en Sevilla - a donde llega a sus trece años junto a su padre, el emsamblador de retablos Miguel Cano, y su familia-, en Madrid, para donde parte en 1638 bajo la protección del Conde-Duque de Olivares, y desde donde, pasados trece años, vuelve a Granada para trabajar en la catedral, ocupando una de las vacantes de beneficiado dotada para música de voz, y a pesar de lo mucho hecho y de la alta calidad de su obra, no ocupa aún Cano el lugar y prestigio que pensamos le corresponde.

Ciertamente que su obra, fundamentalmente de tema religioso y realizada con destino a iglesias y conventos, no tuvo el respaldo ni la posterior fortuna crítica - salvo determinados tiempos- que la de su compañero de taller Velázquez, sin que las mejores obras de ambos justifiquen tantas diferencias de fama y reconocimientos. A su propia vida accidentada e, incluso, muy posiblemente a su propio carácter difícil y a veces violento y orgulloso y también al ambiente sociológico tan poco favorable a la consideración y al bienestar de los artistas en general, habrá que achacar, junto a lo cambiante de las modas y de los gustos artísticos, que su existencia no fuera lo brillante que indiscutiblemente su obra merecía y merece. En este sentido, ya en 1926, Gómez-Moreno Martínez decía:

ro del Valle sólo cita 4; Palomino fija en 13 su producción escultórica; Gómez-Moreno Martínez catalogó en 1926 hasta 44 y desechó otras 31, ofreciéndose en la Exposición de 1945, en el Palacio de Carlos V, sólo 19 obras, según el Catálogo hecho por M." Elena Gómez-Moreno. En 1967-68, en la Exposición celebrada en el Hospital Real de Granada, para conmemorar el III Centenario de la muerte del artista, se expusieron un total de 16 esculturas. Wethey estableció, en la versión en español de su monografía, el catálogo de la producción escultórica en un total de 24 esculturas. M." Elena Gómez-Moreno, en su volumen de Ars Hispaniae (1963), considera 27 obras como seguras del maestro. En mi trabajo sobre el «El arte barroco en Andalucía» (1991) estudié un total de 24, dejando sin comentar algunas atribuciones anteriores por la obligada síntesis que el tipo de obra imponía. En esta línea apuntada por el profesor Urrea y como propuesta concreta y nota fínal al presente trabajo, incluyo una relación detallada de lo que considero puede ser la propuesta de catálogo con un total de 31 esculturas. 
«Mientras realismo y naturalismo a secas fueron banderín de la crítica, lógicamente se le regatearon méritos; más ahora, que la expresión de vida sin contenciones y sin norma seduce, orientando hacia modalidades de arte con prentensiones de nuevas, Cano sigue desdeñado igualmente, y su barroquismo, sin inquietud espiritual para crear, no encarna en el ideario puesto de moda. Goza hoy de predicamento su escuela; él queda en una penumbra de respetuosa benevolencia, casi como la que envuelve a Pacheco frente a Velázquez...» $»^{4}$.

Habiendo cambiado las cosas desde entonces, Cano sigue aún injustamente un tanto desplazado respecto a otros nombres que en verdad no le superan: Ribalta, Gregorio Fernández, Zurbarán, Murillo o Valdés Leal, por ejemplo. Este genial artista posiblemente hubiera necesitado acompasar su carácter con el oportuno y suficientemente mantenido mecenazgo, para que su excepcional sentido de la belleza, su refinado gusto en la composición, su valentía en sus conceptos de los volúmenes escultóricos, su modernidad de diseño en la arquitectura y su riqueza equilibrada de paleta hubieran triunfado, como todavía hoy su obra reclama.

Con relativa frecuencia la crítica historiográfica ha hecho derivar de su diletantismo más consecuencias negativas que positivas, cuando es precisamente, según creemos, el enriquecimiento de estos múltiples quehaceres y experiencias el que confiere siempre a su obra esa plenitud y amplia polivalencia. Porque, más que valorar sus propias y múltiples capacidades en las diferentes artes, la crítica ha olvidado generalmente su profunda cualidad de hacer unívoco y denso lo múltiple y variado que a cada lenguaje artístico que él practicó corresponde. Porque con la obra de Cano habría que actuar tal como en parte se propone en el Tratado de la Pintu$r a$ de Leonardo, donde en su primera parte, el «Paragone», se analiza comparativamente la pintura con la poesía, la música y la escultura, más que para marcar los elementos que las diferencian, para considerar lo que de común tienen para llegar a la obra total y plena. Resuena así (con los oportunos matices) en esta tesis de Leonardo la afirmación del lema horaciano de ut pictura poesis.

Y este completar entre sí las sólo aparentemente distintas ocupaciones, que, como distintas en verdad, merecen diferentes procedimientos y técnicas, pero no incompatibles empeños y finalidades, nos lo recuerda el pasaje que narra el pintor Palomino, ya tantas veces referido y que, fuese cierto o no, son las obras y comunidades de conceptos plásticos las que lo hacen verdad irrefutable:

«Solía algunas veces nuestro Cano, cansado ya de pintar, pedirle a el discípulo (que lo asistía) las gubias, el mazo y otros instrumentos, para trabajar de escultura, diciendo que quería descansar un rato. Reíase de esto el mancebo, y le decía: Señor ipues es buen modo de descansar, dejar un pincelito y tomar un mazo! A que respondió el Racionero: ¡Eres un gran mentecato! ¿Ahora ignoras que es más trabajo dar forma y bulto a lo que no lo tiene; que dar forma a lo que tiene bulto? Sentencia digna de observar en quien practicaba ambas facultades; y que no la dictó la pasión de una, ni otra, sino la fuerza de la razón y la experiencia de ambas. Y así le decía a D. Juan Niño (su discípulo) que en ninguna de las otras tres artes, que manejaba, hallaba tanta dificultad como en la Pintura; de suerte, que trasudaba, para hacer cualquier cosa» ${ }^{5}$.

\footnotetext{
${ }^{4}$ Gómez-Moreno Martínez, M., «Alonso Cano, escultor», Archivo Español de Arte y Arqueología, II. (1926).

5 Palomino y Velasco, A., Museo pictórica y escala óptica, T. III, «El Parnaso Español pintoresco laureado». Madrid, Aguilar, 1947, p. 992.
} 
Independientemente de otras consideraciones que el pasaje nos permitiría, interesa destacar en él su principal comunión con lo escultórico y la indiscutible y permanente presencia de la intención plástica del volumen en su pensamiento artístico, ya fuera dicho éste con el color sobre el lienzo o sobre la propia escultura policromada o con las estructuras y decoraciones ornamentales arquitectónicas de los dibujos y de los retablos.

Lo esencial del planteamiento que aquí también abordamos es, además de considerar las diferencias esenciales de conceptualización de cada una de las artes —aquí plásticas - en relación al natural como objeto de la mímesis, exponer el caso singular de un solo artista circulando entre diversas artes que, aunque hermanas, son diferentes. Y esta multiplicidad creadora, muchas veces sobre un mismo tema y objeto, hace venir fácilmente a la mente ejemplos modélicos, creadores de trascendentes doctrinas, tales como Leonardo, Miguel Ángel, Rafael; y consecuencia de ellos y de la propia ideología estética del humanismo, casos más cercanos a nosotros, como los de Alonso de Berruguete, Machuca. En tiempos posteriores al neomanierismo de principios del siglo xvII, que reacciona a la instancia naturalista primera y contramanierista anterior, se encuentra un Alonso Cano que desde el sentimiento de lo barroco se inspira en un neoplatonismo idealizador, rico de contenidos religiosos tan propios y activos de la época. Son sus pinturas ajustados complementos a sus propias versiones escultóricas y éstas verdaderas composiciones que precisamente se concretan y definen en gran parte en el color. Tampoco está ausente de su obra arquitectónica la emoción plástica y de claroscuro propia de lo escultórico.

Pero estudiar desde esta fenomenología estos casos de artistas polifacéticos se puede convertir en lugar común, o por lo menos prestarse a confusión, si sirven de excusa para difuminar las diferencias entre las distintas prácticas artísticas. Pensamos que probablemente haya, por lo menos, una jerarquía cualitativa o una primacía hasta incluso y en cierta manera dependiente de factores de la propia psicología y temperamento del autor. Pero todo esto no implica que un arte dependa de otro en abstracto, ni siquiera en estos ejemplos individualizados y personales. Para cada caso de un pintor dado que esculpa o de un escultor que pinte es concebible que ambas prácticas puedan ser absolutamente autónomas. No basta saber que el autor de obras pertenecientes a artes distintas es el mismo para resolver el problema de independencia o de préstamos entre los diferentes lenguajes. Para concluir que hay una relación, se debe demostrar mediante la comparación entre obras concretas. Sólo entonces cabe decidir si existe cierto grado de influencia o contaminación entre las diferentes prácticas artísticas o si pueden, incluso, responder a un mismo programa y credo estético.

La afirmación de Cano de que descansaba con las gubias del trabajo con los pinceles, aparte de otras significaciones directamente referidas a la propia naturaleza del arte de la pintura y de la escultura, nos comunica los límites esenciales que existen entre ambas prácticas artísticas. El desplazamiento entre las artes se revela así como la superación de ese o esos límites, entendidos no sólo como límites-frontera que las separan, sino natural limitación a la que está sometida cada una y así el artista se pasa de bando al afrontar las barreras de su propio ejercicio, cayendo en la práctica metafórica ya siempre referida a la otra práctica artística de la que toma prestado algo de su propia naturaleza.

Pero acercarse a los límites de las artes en las que se está creando implica, asimismo, forzar la voluntad de superación de esos límites por parte del sujeto creador, que así se introduce en la búsqueda de algo más completo, que aspira a llegar más allá de esos límites propios del lenguaje practicado y a los que tiende a superar. Esto supone adentrarse en la práctica de las artes en relación entre sí, o también practicar el reto o el gesto de volcarse hacia otro espacio creador para experimentar así ese tránsito a lo múltiple desde un solo sujeto creador.

Pongamos un ejemplo: 


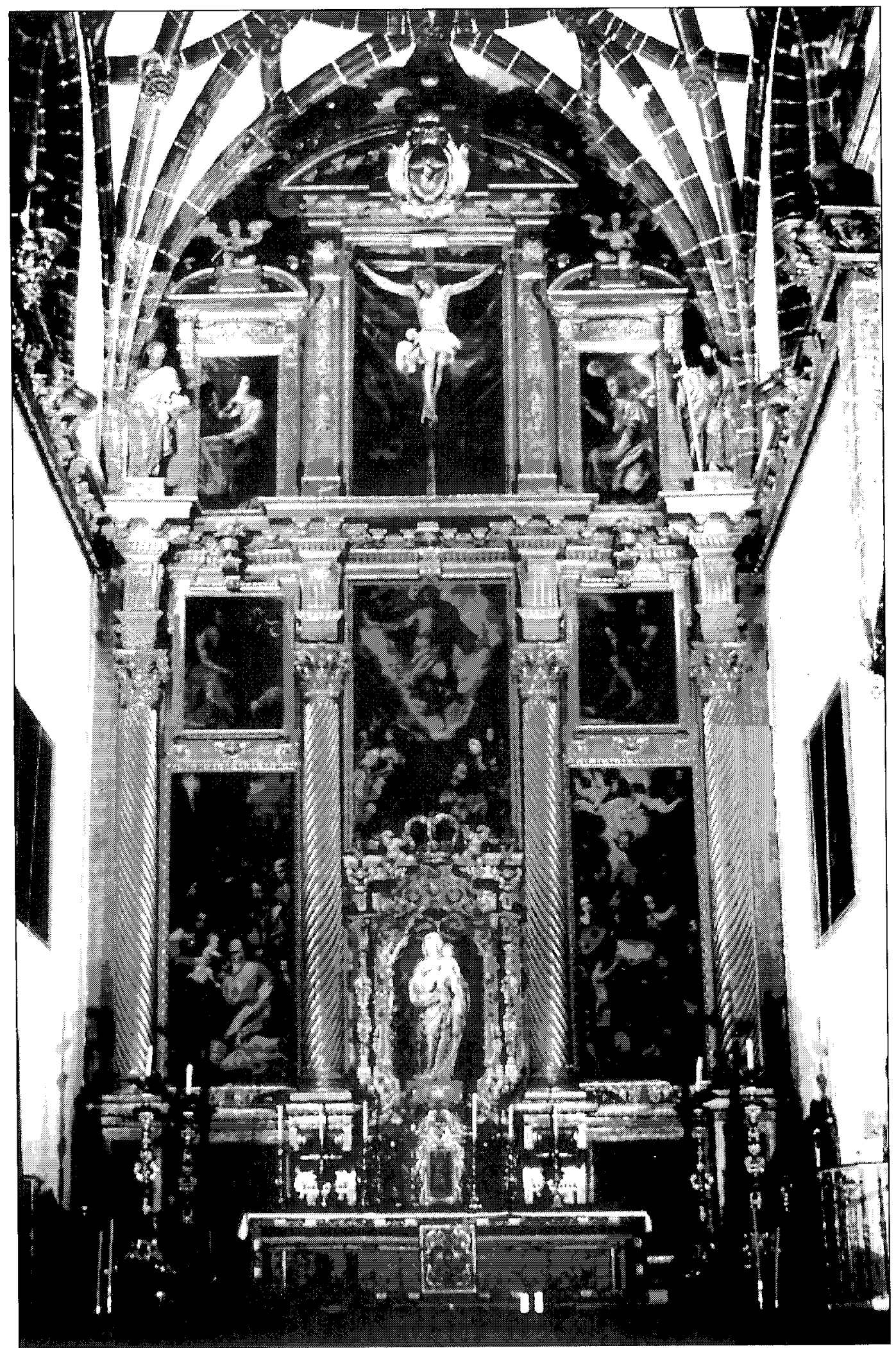

Fig. 1. Retablo del Altar Mayor de la Parroquial de Lebrija (Sevilla). 
No se trata ya sólo de ponderar los valores puramente arquitectónicos y, en cierta manera, revolucionarios y nuevos de las soluciones que Cano crea en el gran retablo de la parroquial de Lebrija en 1629, con la rotunda presencia de las cuatro monumentales columnas peraltadas por los entablamentos exentos y todo de un solo cuerpo y un ático - tal y como ya había practicado de manera parecida el hermano Alonso Matías en 1606 en la Casa Profesa, como bien recordó el profesor Rodríguez Gutiérrez de Ceballos ${ }^{6}$-, sino de atender, en estudio comparado, lo que de este monumentalismo arquitectónico está presente en las esculturas del retablo y en especial en la misma imagen de la Virgen de la Oliva, que como teotocos-columna muestra solemne y poderosa al Salvador, sin que el atormentado camarín-hornacina posterior pueda disminuir un ápice la razón arquitectónica de este ejemplo de escultura que, a su vez, refrenda con la policromía del manto en relieve la plenitud plástica del plegado, amplio, valiente y en todo escultórico.

Veinte años antes el propio Montañés, en su llamada etapa triunfal, en una plástica plenamente escultórica postmanierista, sin esos préstamos y metáforas de lo arquitectónico, sólo ofrece el estatismo menos esbelto y más macizo, más naturalista y humanizado, de la Virgen con el Niño de la capilla del Reservado de Santiponce, que, aunque ricamente policromada por Pacheco, no alcanza - aún teniendo en cuenta su menor tamaño- aquella compenetración de lo pictórico y de lo escultórico de la Virgen de la Oliva, policromada o por Cano directamente o, bajo su dirección, por Pablo Legot ${ }^{7}$.

Si dos cosas se comparan es porque en esencia son distintas, aunque existan también partes o aspectos de su ser, si no comunes plenamente, cercanos como metáforas. Y así definió Aristóteles la metáfora: «dar a una cosa el nombre de otra». Para poder decir lo que no puede ser dicho con los medios disponibles o naturalmente propios, se toma o usa una palabra ajena al propio lenguaje o una propia que pueda transcribir el modo y manera del otro género artístico, que dice mejor por sí con natural facilidad lo perseguido. Porque, como afirma Antonio Monegal en su trabajo titulado En los límites de la diferencia. Poesía e imagen en las vanguardias hispánicas:

«Sin comparar, sin embargo, sólo podemos pensar lo particular. Sin generalizaciones, como nos recuerda Borges en Funes, el memorioso, nos quedamos atascados en la diferencia, en un mundo de casos excepcionales y únicos, donde pensar es imposible. Pero la diferencia existe y siempre es, hasta cierto punto, insalvable ${ }^{8}$.

Pero también limitarse a contrastar simplemente la diferencia, sin traspasarla, es quedarse en una pseudoarqueología denunciadora o mero ordenamiento formalista y jerarquizado de los elementos.

Esta obra señera de la originalidad creadora de Cano, aún a edad relativamente joven, ya que el gran retablo de Lebrija fue diseñado por el artista a los 28 años, es ejemplo expresivo para reflexionar también sobre estas cuestiones de interrelaciones entre las distintas prácticas artísticas a las que se dedicó. Porque las soluciones que hacen que esta obra sea un punto y aparte respecto a lo anterior, no sólo se encuentran en lo estrictamente original de los elemen-

\footnotetext{
"Rodríguez Gutiérrez de Ceballos, A., «Alonso Matías, precursor de Cano», Centenario de Alonso Cano en Granada. Estudios (1969), pp. 165-201.

7 Sánchez-Mesa Martín, D., «La policromía en las esculturas de Cano», Centenario de Alonso Cano en Granada. Estudios, (1969), pp. 231-247.

${ }^{8}$ Monegal, A., En los limites de la diferencia. Poesía e imagen en las vanguardias hispánicas. Madrid, Tecnos, 1998, pp. $15-16$
} 

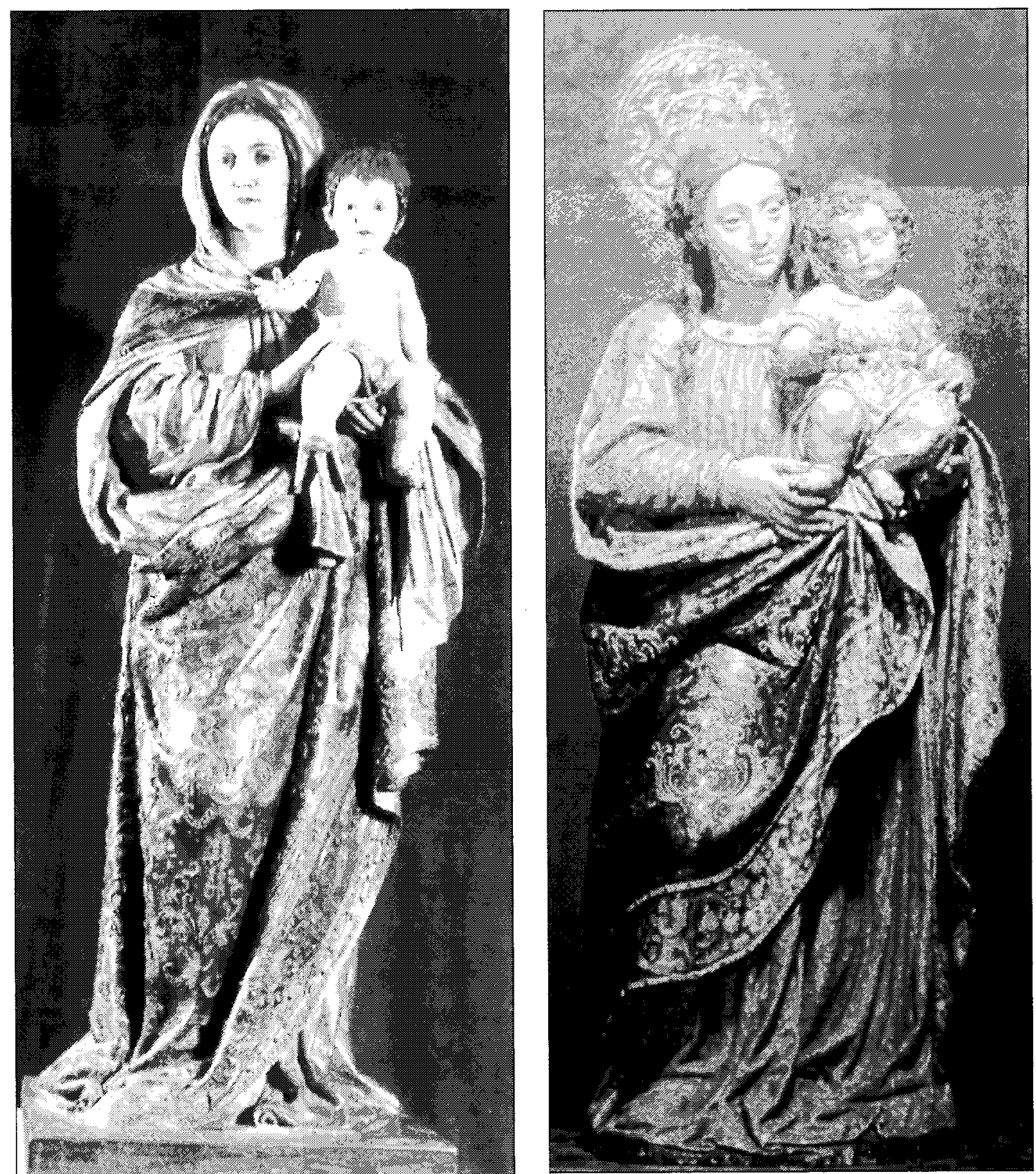

Fig. 2. Virgen con el Niño. Retablo de Lebrija.

Fig. 3. Martínez Montañés: Virgen con el Niño. Santiponce (Sevilla).

tos arquitectónicos, sino también - y esto es lo que aquí más nos interesa - en los propios elementos escultóricos ideados especialmente para el retablo, para ocupar lugares y espacios específicos y concretos.

Por ejemplo, es concretamente significativa la función plástico-arquitectónica que juegan las dos grandes figuras del San Pedro y el San Pablo, tal como era frecuente en el renacimiento recuérdese el gran retablo de El Escorial - y como ocurre en los retablos de Alonso Matías en la Casa Profesa de Sevilla y en el retablo mayor de la catedral de Córdoba, donde actúan también ya como verdaderos remates arquitectónicos sobre las dominantes verticales de las monu- 

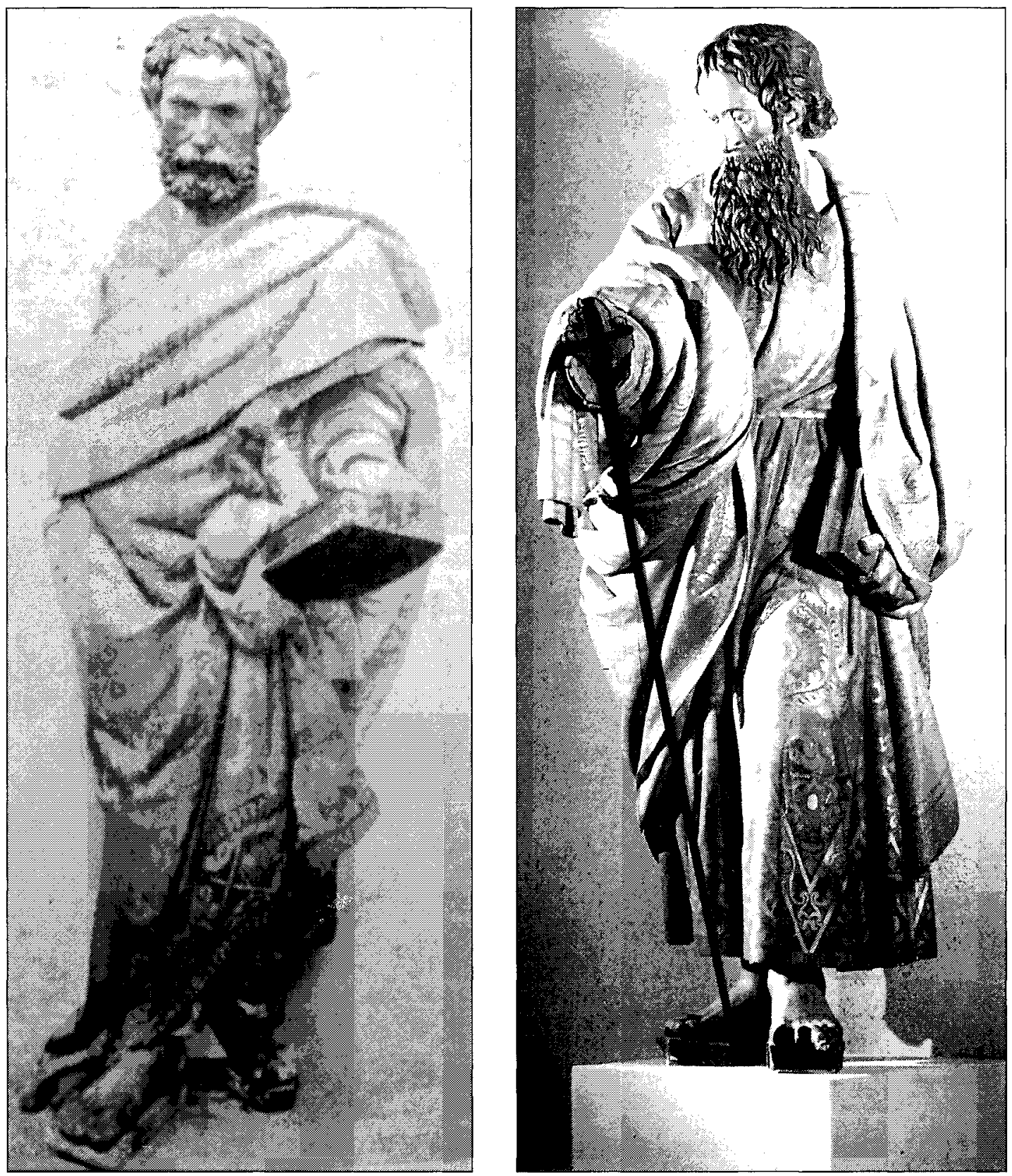

Fig. 4. San Pedro. Retablo de Lebrija

Fig. 5. San Pablo. Retablo de Lebrija.

mentales columnas exteriores de estrías helicoidales y que en Lebrija el contrato especificaba que debían ser «columnas estriadas derechas». Esta variación de ritmos, hecha por indiscutible decisión de Cano, se nos relaciona directamente con el tipo de soluciones compositivas que se incorporan a las propias figuras de los apóstoles citados, resueltas en la tensión plástica expresiva entre el aplomo de la estática vertical y los ritmos oblicuos y de torsión de ejes de hombros, dirección de la mirada y del plegado de los mantos, como «a lo clásico», que ya configuran la línea de ánfora, al estrechar intencionadamente la parte baja y resaltando además todo esto por la propia policromía de los galones de los mantos, pintados sobre oro con sombreados que pro- 
ducen la sensación de relieve ${ }^{9}$. También juegan una especial función plástica y arquitectónica los dos angelotes colocados sentados en los dados situados delante de los frontones partidos, que rematan las calles laterales del ático. El claroscuro y contraste de las esculturas y la composición de sus desnudos, alternando las horizontales y las verticales de las piernas cruzadas y los ritmos abiertos de las alas, refieren y señalan con toda la fuerza del volumen exento y la policromía la función plástico-dinámica de los ritmos de los frontones curvos partidos.

Muchas de estas razones, aparte de las de naturaleza didáctica e iconográfica, de seguro intervinieron también para que se decidiera cambiar lo especificado en el contrato en relación al gran Crucificado que centra el ático del retablo. Estaba estipulado hacerlo de pintura:

«... pasada la cornisa, en el lienzo de en medio se obliga a pintar un Cristo, y a los lados Virgen y San Juan».

Sin embargo y en contra de lo estipulado con Legot para la pintura del retablo, el 3 de enero de 1638, cuando Cano cede el trabajo por su marcha a Madrid, otorga carta sobre el encargo que tiene hecho por el provisor de la iglesia de Lebrija

«... de la hechura de un Cristo para ponerlo en lo alto del altar mayor... sobre el retablo de dicho altar... y no puedo acabar dicho crucifijo, lo encargo dél a Felipe de Ribas, maestro escultor... a quien e entregado el modelo y forma dél de madera para que lo acabe... le entrego el mandamiento de dicho encargo con la figura y el modelo que tenía entregado de dicho Cristo...» ${ }^{10}$.

Independientemente de los problemas que encierra la autoría de esta relevante y enigmática pieza, merece la pena insistir sobre la importancia que supuso decidir el cambio de la pintura por la escultura, que ahora juega con la plenitud del volumen exento un especial efecto de relieve y claroscuro, relacionado tanto con el saliente de cornisa del primer cuerpo, como con los propios volúmenes de las figuras del San Pedro y San Pablo. Se conjugan así los planos adelantados de las cuatro monumentales columnas con la función corpórea de las esculturas, en especial y muy particularmente con la de la Virgen, aunque ahora esta función queda un tanto distorsionada por el barroquismo recargado y de diferente tono estético de la hornacina añadida con posterioridad, privándonos de conocer la solución que el propio Cano dio a un espacio y a un elemento tan esencial, como es la propia escultura de la Virgen de la Oliva, tan intencionadamente cuidada en su frente, perfiles y espalda.

Pero la función de la escultura en el retablo ${ }^{~}$, que nos permite interrelacionar lo arquitectónico y lo escultórico, también se enreda con las estrictas relaciones de lo pictórico y de lo escultórico, especialmente por la condición de ser esculturas y arquitecturas policromadas. Éste es otro capítulo en nada secundario, aunque la historiografía a veces no lo haya considerado con justa valoración o lo haya no sólo ignorado sino incluso menospreciado ${ }^{12}$.

\footnotetext{
9 Sánchez-Mesa Martín, D., «La policromía en las esculturas... (1969), cit. , p. 237: «En el galón se imita rico bordado, limitado por una línea de cuentas con la técnica que llamaban «brocado alto», utilizando para ello el oportuno sombreado». Rodríguez Gutiérrez de Ceballos, A., «Alonso Matías...» (1969), cit. pp. 184-185.

${ }^{10}$ Gómez-Moreno Rpdríguez-Bolívar, M." E., «Problemas en torno al retablo de Lebrija», en Centenario de Alonso Cano en Granada. Estudios, Granada, 1969, p. 215. Sánchez-Mesa Martín, D., «El Crucificado en el arte de Alonso Cano». Cuadernos de Arte, 32, (2001), pp. 105-124.

1 Sánchez-Mesa Martín, D., «La escultura en el retablo: sobre el romanismo de Pablo de Rojas». Archivo Hispalense. Revista histórica, literaria y artística, 249, (1999), pp. 231-250.

12 Significativo de esta circunstancia es la diferente consideración que han merecido nuestros trabajos sobre este tema -ya desde 1967- por la crítica especializada extranjera, como son los casos del profesor Paul Philippot, de la Universidad Libre de Bruselas y del IRPA; de la especialista norteamericana Gilman Proske; de los especialistas españoles Juan José
} 

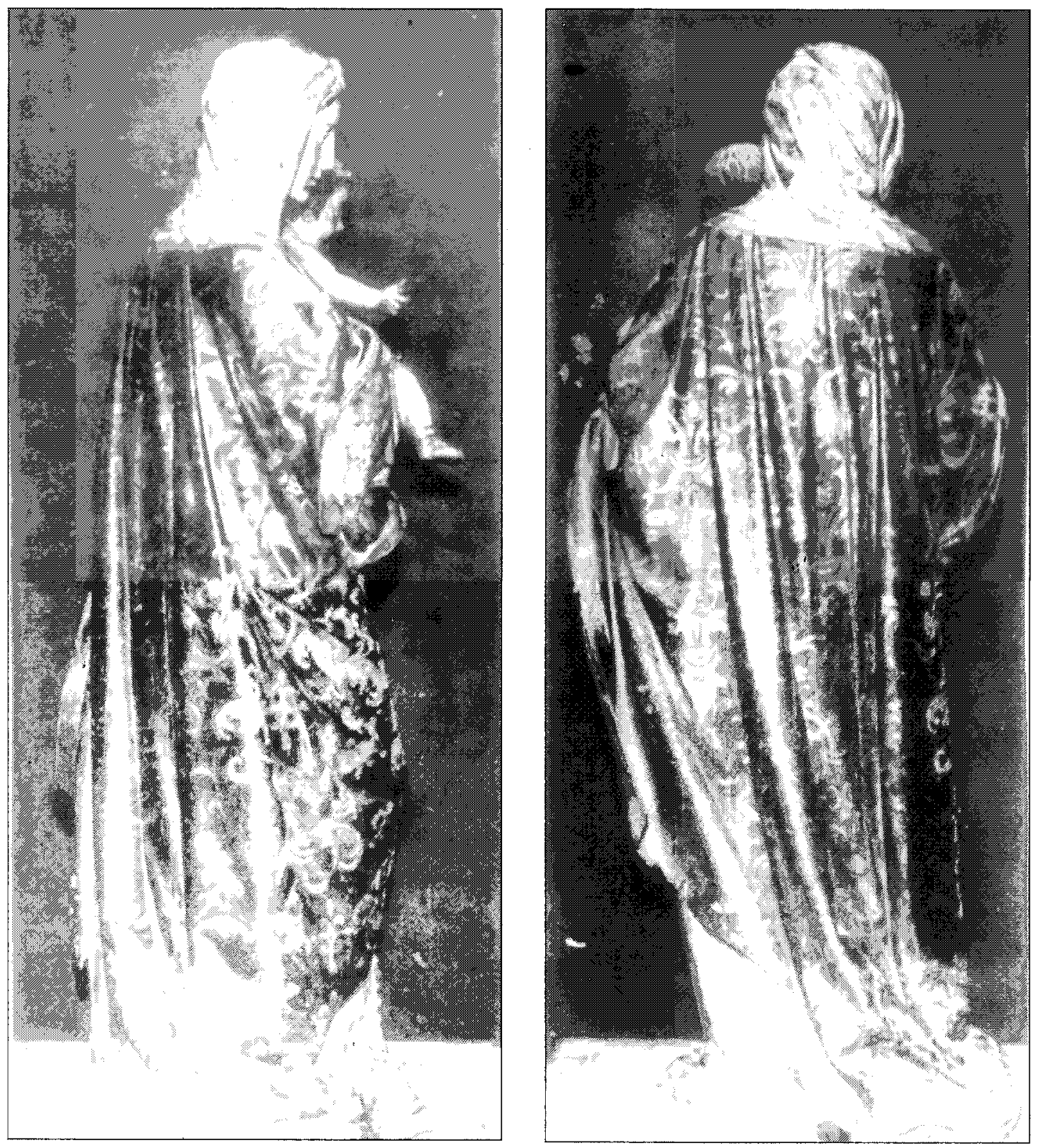

Fig. 6. Virgen con el Niño, de perfil. Retablo de Lebrija.

Fig. 7. Virgen con el Niño, de espaldas. Retablo de Lebrija.

Todavía, y de manera concreta en el caso de Alonso Cano escultor, son pocos los trabajos que se ocupan de estas cuestiones tan relacionadas, por otra parte, con los aspectos estrictamente dedicados al estudio de las técnicas de ejecución de las obras. Si algo se ha hecho en algunos

Martín González o M. Elena Gómez-Moreno, frente a lo hecho por la llamada Comisión Nacional de Evaluación de Investigación del Ministerio de Educación, que en su primera reunión negaban evaluación positiva a libros y trabajos como los siguientes: La policromía en las esculturas de Alonso Cano; La técnica de la policromía en la escultura granadina; José Risueño, escultor y pintor; Nuevas obras de Pedro de Mena, a los que siguieron otras posteriores publicaciones sobre estos temas, que no es el caso ahora de enumerar, y que por supuesto no he vuelto a someter a tan discutible procedimiento de evaluación. 
casos de la obra pintada por Cano ${ }^{13}$, muy poco se ha realizado - o se conoce- sobre la investigación y estudio en esta línea de sus esculturas. Aún hoy no contamos con mínimas informaciones sobre estudios radiográficos, estratigráficos, de análisis de maderas, colas y pigmentos de las obras principales de Cano escultor. Esto, en el caso concreto que nos ocupa, se hace especialmente grave, ya que, al ser Cano un artista que trabajó la escultura frecuentemente sin colaboración de taller propio, nos ofrecería en sus modos y procedimientos técnicos ciertos y valiosos datos directamente relacionados con sus primeras intenciones estéticas y también con los siguientes procesos de su propia y personal investigación creadora. Nada sabemos, mediante investigación de laboratorio, de cómo construía sus embones o de cómo procedería en el proceso de la talla; de cómo resolvería las dudas y los «arrepentimientos», que también existen en escultura; de cómo atacaría el bloque o embón de madera, haciéndolo según un simple boceto o dibujo previo, o por el procedimiento de sacado de puntos, siguiendo un boceto o modelo en barro o cera de los que nada conocemos. Nada de esto sabemos, ni nada se está haciendo, salvo en algunos procesos de restauración que tampoco se llevaron a cabo con el rigor científico y profesional que es exigible (caso de la Santa Teresa del Buensuceso o la restauración de la Inmaculada de San Julián o lo que se hizo antes con el Crucificado de Lecaroz).

Se está, generalmente, en el error al creer que hace falta intervenir, ya limpiando o restaurando para poder conseguir los datos referidos y no es así. La conservación de la obra obliga a un conocimiento previo y permanente lo más exhaustivo posible de sus estructuras y soportes. La intervención es algo supeditado a otras circunstancias. En la escultura policromada, el limpiar por limpiar ocasiona incluso serios y graves problemas de pérdida de pátinas, que están directamente relacionadas con aspectos esenciales de blanduras, durezas o matices del propio modelado y talla. La relación del trabajo de la talla con su posterior policromía alcanza especiales niveles de importancia en el caso de Alonso Cano, ya que en muchas de sus esculturas se funden y se complementan sus propias visiones pictóricas de lo escultórico y viceversa. Se da la circunstancia especial de que él era escultor que tallaba y pintor que policromaba. Que esta labor de la policromía y su especial valoración como actividad destacada fue ya así considerada en el propio mundo de los tratados de la época es buena prueba que ya se vea corroborada por Pacheco, su maestro en pintura, y por las posteriores opiniones de Palomino. Éste último, al hablar sobre los artistas granadinos hermanos García, de fines del xvı y principios del xvi nos dice:

«... pero, según parece, el uno era eminente, o se señalaba más en hacer efigies de bulto y el otro en colorirlas, o pintarlas, que no es lo menos importante, pues muchas buenas esculturas vemos echadas a perder por mal encarnadas o coloridas, y otras las sublima de modo que las acrece otro tanto de primor y estimación, como lo vemos en las de Cano, Herrera, Mena, Mora y otros» ${ }^{14}$.

A su vez, Pacheco nos dice:

«De las encarnaciones de bulto, hay mucho que decir, que es parte de la pintura al olio, y no se deben tener en poco». Sobre la policromía en pulimento afirma: «... y es bien usarla en mala escultura, porque con las luces y resplandor, se disimulan los defectos» ${ }^{15}$.

\footnotetext{
13 A finales de los 90, el profesor de la Facultad de Bellas Artes, de la especialidad de Restauración, de la Universidad de Granada, Luis Rodríguez Simón, defendió su tesis doctoral, dirigida por mí, en la que se ocupaba del estudio y análisis téenico de obras pintadas sobre lienzo por Alonso Cano existentes en el Museo de Bellas Artes de Granada, con estudios radiográficos, estratigráficos y de pigmentos.

${ }_{14}$ Palomino y Velasco, A., Museo Pictórico... (1947) ob. cit., p. 529

is Pacheco, F., Arte de la Pintura. Edición de F.J. Sánchez Cantón. Madrid. Instituto Valencia de Don Juan. 1956. pp. $101-109$.
} 


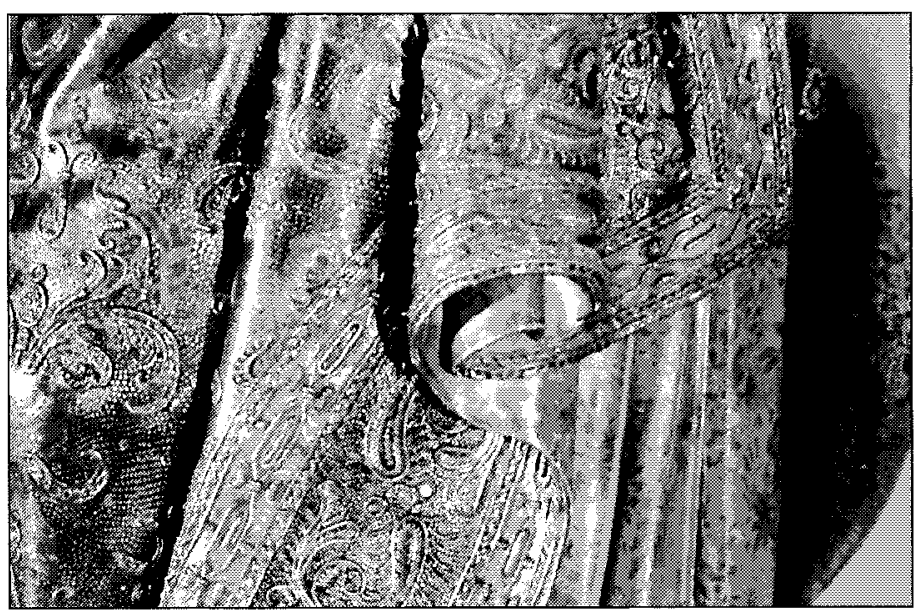

Fig. 8. Detalle de la policromía del manto de la Virgen. Retablo de Lebrija.

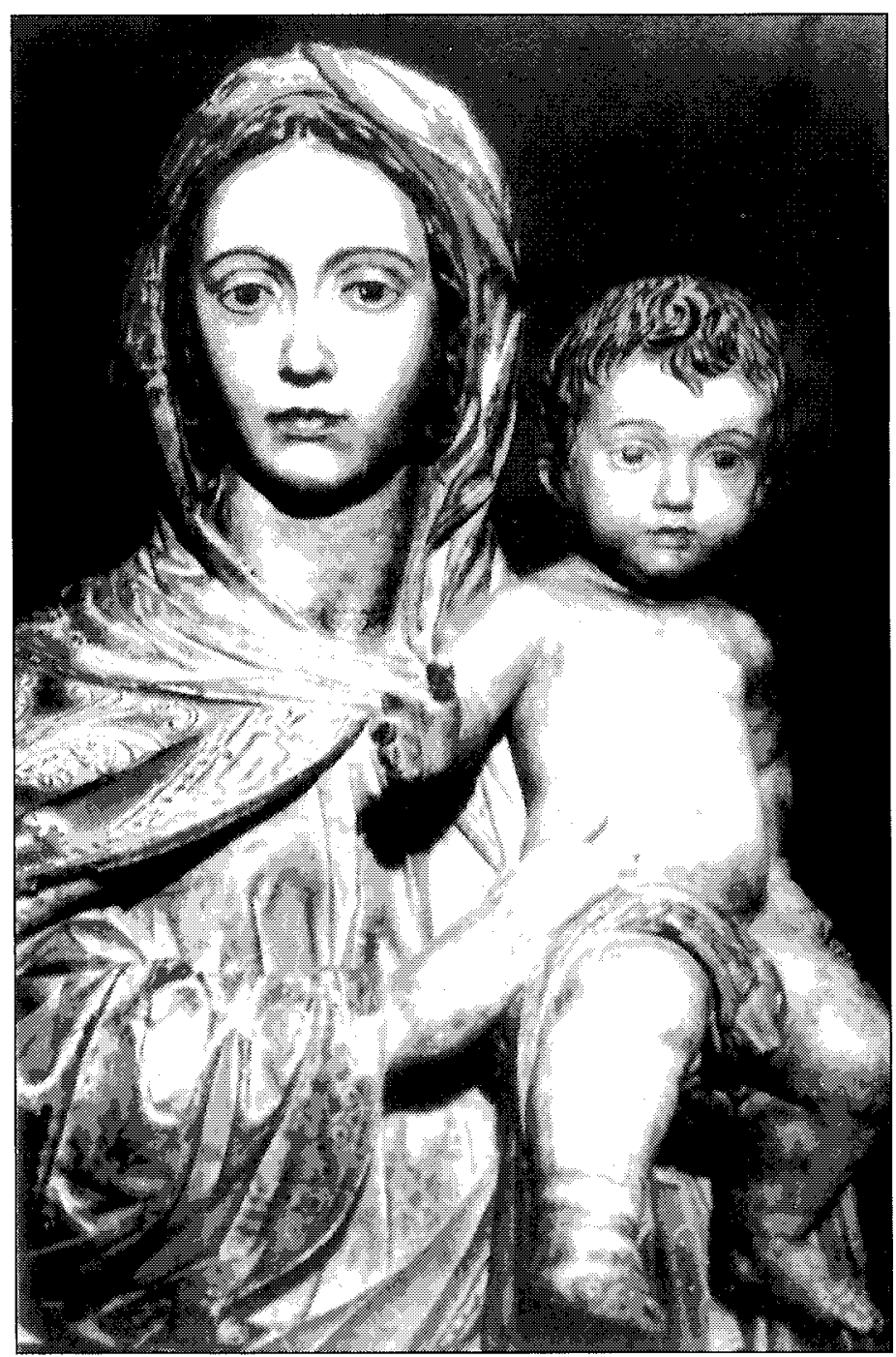

Fig. 9. Virgen con el Niño (detalle). Retablo de Lebrija.
De cómo la policromía se compenetra con la intención escultórica y de cómo el estudio de la escultura de Cano queda incompleto o, incluso, mal entendido sin la valoración del elemento color, es interesantísimo ejemplo, dentro de esta etapa sevillana, la ya referida Virgen de la Oliva, titular del retablo de la parroquial de Lebrija, y en la que ya antes hemos podido valorar sus propios contenidos arquitectónicos, materializados en sus formas escultóricas.

La imponente y serena vertical con que decididamente se nos presenta esta figura, que nos muestra al Niño Dios, se consigue en gran modo y por contraste en parte con ese amplio plegar escultórico de su manto, dejando libre el brazo derecho, que, por su dibujo y ritmo, nos lleva hasta la figura del Niño y se recoge pesadamente debajo de Él en la mano y brazo izquierdo. Son estos amplios pliegues, totalmente diferentes a los de la escuela escultórica castellana de un Gregorio Hernández, los que en una visión pictórica serían tema ideal para valorar el claroscuro propio de una etapa tenebrista, como se puede apreciar en el San Francisco de Borja (1624), en el San Juan Evangelista de la antigua colección Castell o en el propio Santiago del Louvre. Pero la rotunda valentía de estos pliegues no se definirían tan plásticamente sobre una tela de apariencia fina, más apropiada para el plegado menudo, sino sobre un paño donde el propio 
relieve del bordado exige grosor y, por lo tanto, peso. El pliegue tiene que vencer el grueso de las telas, dando como resultado un dibujo amplio y bien definido. La diagonal del manto, que conduce hasta el punto más destacado de la composición, el Niño desnudo y de carnaciones claras, se acentúa y refuerza plástica y pictóricamente con un ancho galón con adornos de ritmo ondulado en forma de ese, enmarcado por dibujo de cadeneta. Todo este brocado y bordado está hecho en relieve y con el aparejo sobre la talla, en la técnica de barbotina, a la que en los documentos se le llama «brocado de tres altos» y en la que el sombreado es real y no pintado. Como antecedentes, aparte de otros ejemplos más cercanos en obras de Montañés, podemos recordar, incluso, las labores realizadas de adornos en relieve sobre tablas hispanoflamencas y la policromía conocida en los documentos como «picado de lustre».

El resto de la figura, cuidada en sus cuatro perfiles como un todo exento y no de mera silueta plana, insiste en esa solemnidad vertical, contrastando con el azul del manto los tonos claros de la túnica y la toca, salpicados de ramos y flores pequeñas y con plegado más menudo y entrecortado. La solución de plegado del manto por la espalda, con policromía sin relieve, es todo un acierto de elegancia y soltura, como lo son todos sus perfiles contrastando el contraposto y las verticales.

Y, si estos valores pictóricos se funden y compenetran tan magistralmente con la propia entidad de la escultura en cuanto a composición y plegado se refiere, muy frecuente en pinturas manieristas, más acierto supone aún la talla y policromía del rostro de la Virgen y del desnudo del Niño, sostenido en original postura y en todo totalmente diferente ya a los tipos de Vírgenes frecuentes en el arte de Montañés y en el de Juan de Mesa, menos pensantes y más impersonales y ausentes. Siendo, como lo es, una obra de su primera época como escultor, Cano alcanza la categoría de todo un prototipo, tanto en las formas como en los contenidos, que no llegará a superar ni a igualar hasta que realice su pequeña Inmaculada del facistol de la catedral de Granada (h.1655), donde de manera aún más depurada vuelve a fundirse su arte de escultor y de pintor.

Del resto de obras de escultura atribuidas a Cano en su etapa sevillana habría que destacar, junto a sus Inmaculadas dibujadas y talladas — las de San Julián y San Andrés y la pétrea de la parroquia de Nervión - la figura de San Juan Bautista, antes en la Colección Güell y hoy en el Museo Nacional de Escultura de Valladolid, pieza que, tras su acertada limpieza, es ejemplo principal de la versatilidad y habilidad compositiva que Cano tenía ya como principal maestro escultor y pintor hacia 1634. De nuevo resaltan aquí los perfiles y valores de naturaleza pictórica como acento y complemento de los propiamente espaciales que la composición escultórica ofrece. Muy distante queda de este San Juan Bautista el San Juan Evangelista, más confuso y blando de modelado, del Convento de Santa Ana, cercano a otras manos más próximas al taller de los Ribas, aunque con indudables aciertos y finuras poco frecuentes en estos autores, incluso en Felipe ${ }^{16}$.

Difícil se hace, por otra parte, conceder la autoría de Cano al barro considerado como boceto presentado por el artista para la escultura, después realizada por Montañés, para el retablo del santo evangelista en Santa Paula de Sevilla. Aunque conocido y publicado, lo encontramos falto de la finura y brío que el artista granadino practicaba ya por estas fechas, aún considerando su posible condición de boceto y sus repintes posteriores ${ }^{17}$.

Pero el arte de Cano, tras estas intervenciones entre lo escultórico, lo pictórico y lo arqui-

\footnotetext{
${ }^{16}$ Dabrio González, M." T., Los Ribas un taller andaluz de escultura del S. XVII. Córdoba. 1985, p. 376: «... atribución que debe ser tomada con ciertas precauciones toda vez que faltan elementos de juicio que consideramos fundamentales para poder decidir al respecto».

17 Arteaga, Sor Cristina de, «El altar de San Juan Evangelista de Alonso Cano y una maqueta del santo que está reclamando su paternidad». Centenario de Alonso Cano en Granada. Estudios. Granada, 1969, pp. 219-222.
} 

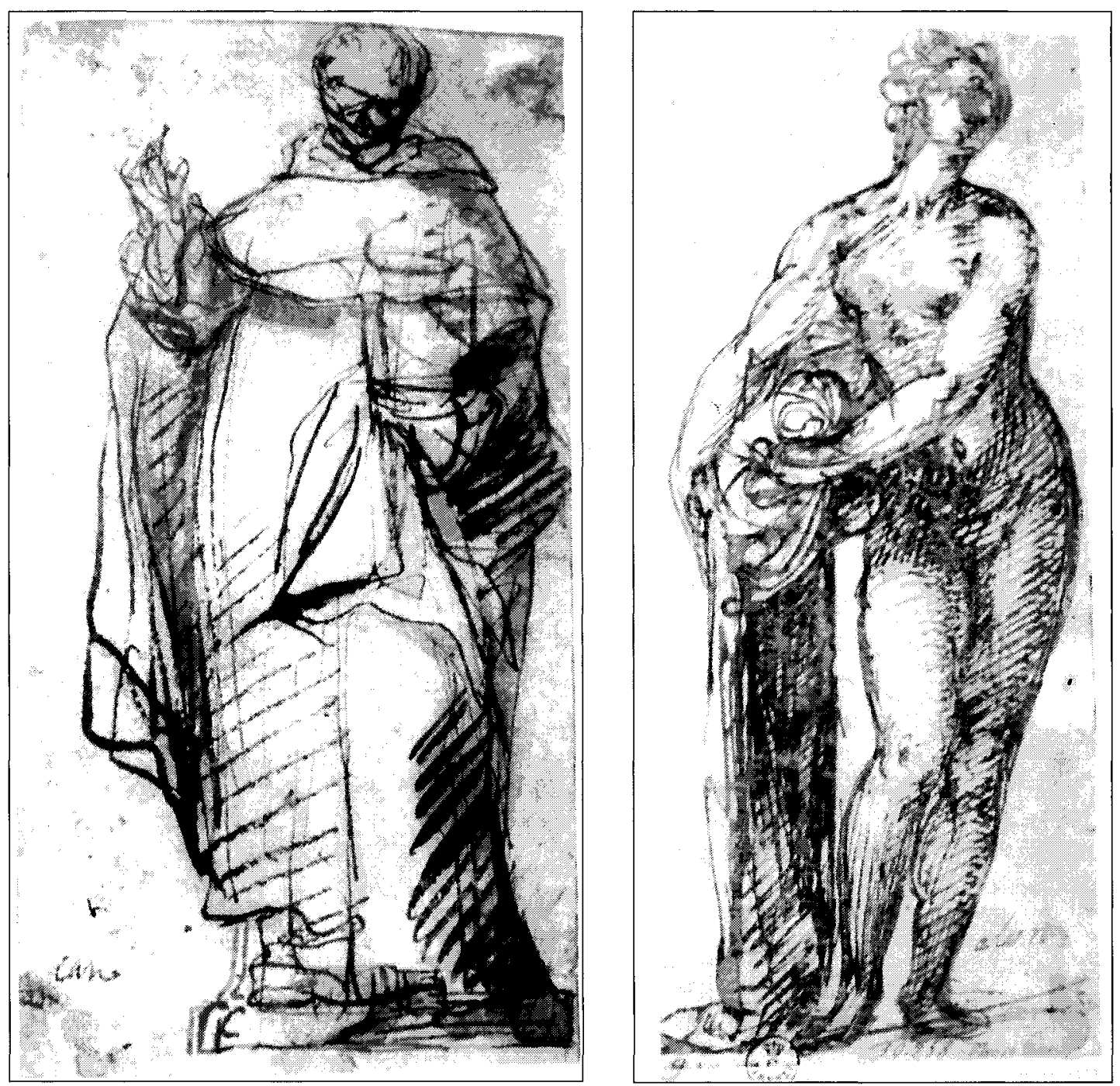

Fig. 10. Dibujo de S. Gonzalo de Amarante. Real A. de San Fernando.

Fig. 1 1. Dibujo de desnudo femenino. Museo Uffizi, Florencia.

tectónico presentes en sus obras sevillanas, se agudiza en su multiplicidad a partir de sus estudios y experiencias madrileñas, en las que la pintura y el dibujo sobresalen, pero sin que en estas prácticas fuese relegada su sensibilidad y su visión plástica de escultor. Casos como los dibujos de San Gonzalo de Amarante, de la Real Academia de San Fernando, (h. 1645), el de Santo Domingo de la misma fecha y lugar, el que representa a Cristo flagelado recogiendo sus vestiduras de los Uffizi de Florencia, o incluso sus versiones de desnudos femeninos del Prado y de los Uffizi, demuestran evidentemente que la mano que los traza y la sensibilidad que los concibe ha experimentado y experimenta en la tridimensionalidad de lo escultórico, característica que en él se hace esencial y permanente.

Así ocurre, una vez más y ya a mediados del siglo xvil, pero ahora en las otras dimensiones de lo espacial y lo pictórico, ante el reto que suponía la realización de la serie de la Vida de la Virgen para la Capilla Mayor de la Catedral de Granada, donde vuelve al Renacimiento y busca traducir, en el más genuino lenguaje pictórico barroco, la monumentalidad espacial unitaria de la obra de Siloe. 

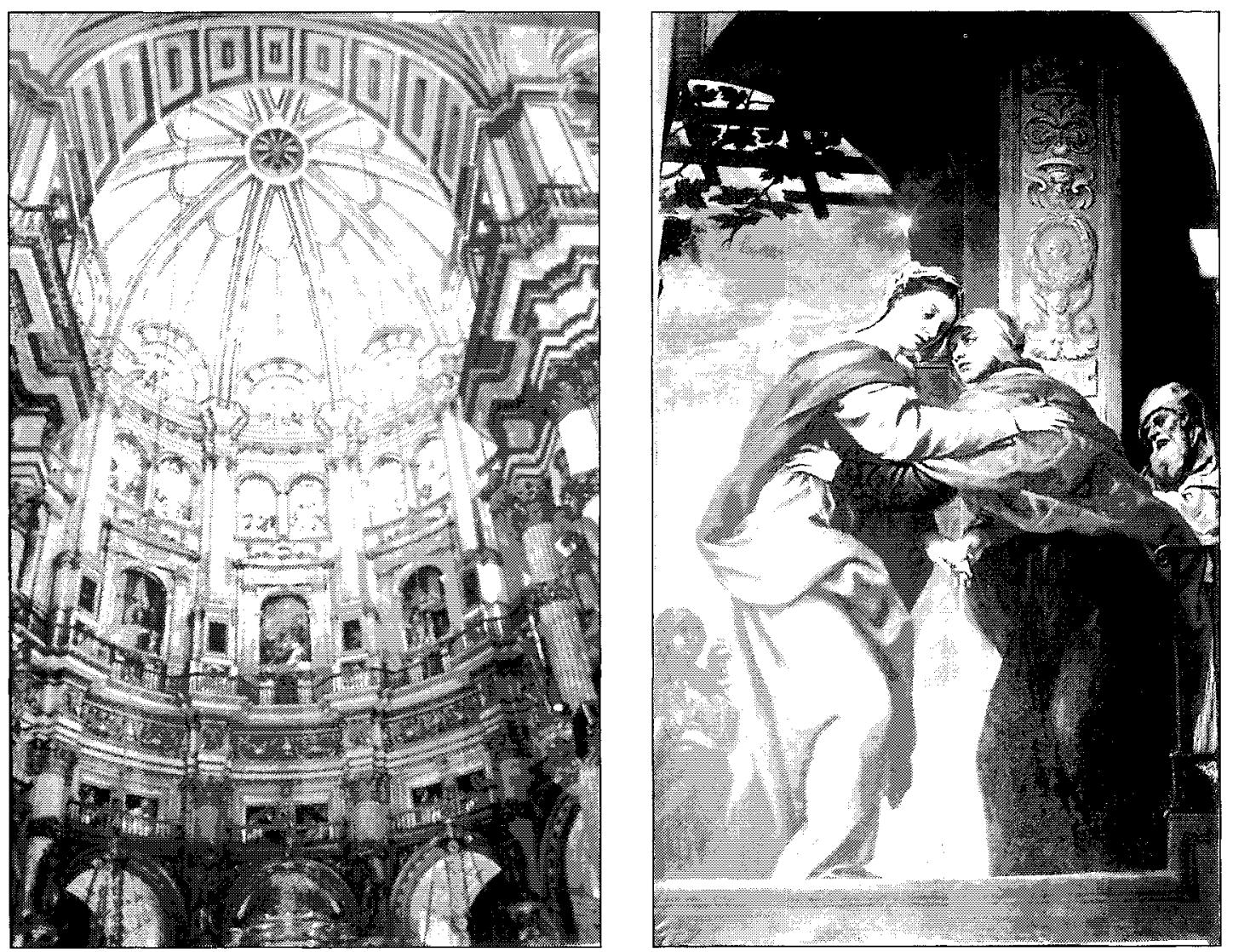

Fig. 12. Capilla Mayor de la Catedral de Granada, con la serie de la Vida de la Virgen.

Fig. 13. La Visitación. Catedral de Granada. de la serie de la Vida de la Virgen.

Si en la teoría más tradicional comparar la pintura con la poesía es hacer una metáfora, Cano, acentuando literalmente las diferencias entre pintura, escultura y arquitectura, produce, sin saltarse las fronteras, objetos más que complementarios, cuasi sinónimos y similares, que crean una poética común y múltiple. De toda la serie, en el lienzo en el que de manera más ajustada alcanza esta metáfora pictórico-arquitectónica es en el de Visitación (1653). La monumentalidad casi de naturaleza escultórica de las dos figuras transcribe con lenguaje pictórico la propia monumentalidad espacial del entorno arquitectónico, tomando de él la dinámica de los escorzos y de las proporciones, tal como vemos ocurre en el monumental apostolado en las columnas del primer cuerpo realizado por los escultores Pablo de Rojas y Bernabé de Gaviria. En otros lienzos este feliz acierto se empequeñece y aminora, como en el caso de la Natividad de la Virgen (1663-54), el de la Presentación de la Virgen en el Templo (1664), o el de la Purificación (1655-56). En el caso de la Asunción (1662) la dinámica ascendente está aquí más lograda con los gestos que en el propio lenguaje de lo arquitectónico-espacial, siendo, por otra parte, una obra espléndida de composición y de resolución plástico-pictórica.

Pero, esta afortunada y compenetrada relectura que Cano pintor hace de la obra de Siloe, desde la nueva dinámica del barroco, no se cumple finalmente con la misma plenitud en su principal obra de arquitectura, la gran portada principal de la catedral, que él proyecta un año antes de su muerte y otros acabaron sobre su proyecto en el s. xvilı. Las intervenciones posteriores — dejando aparte la de Risueño-, especialmente las realizadas por los escultores Verdiguier en el XVIII, no traducen ese sentido de simplificación tectónica que el diseño de Cano crea. 


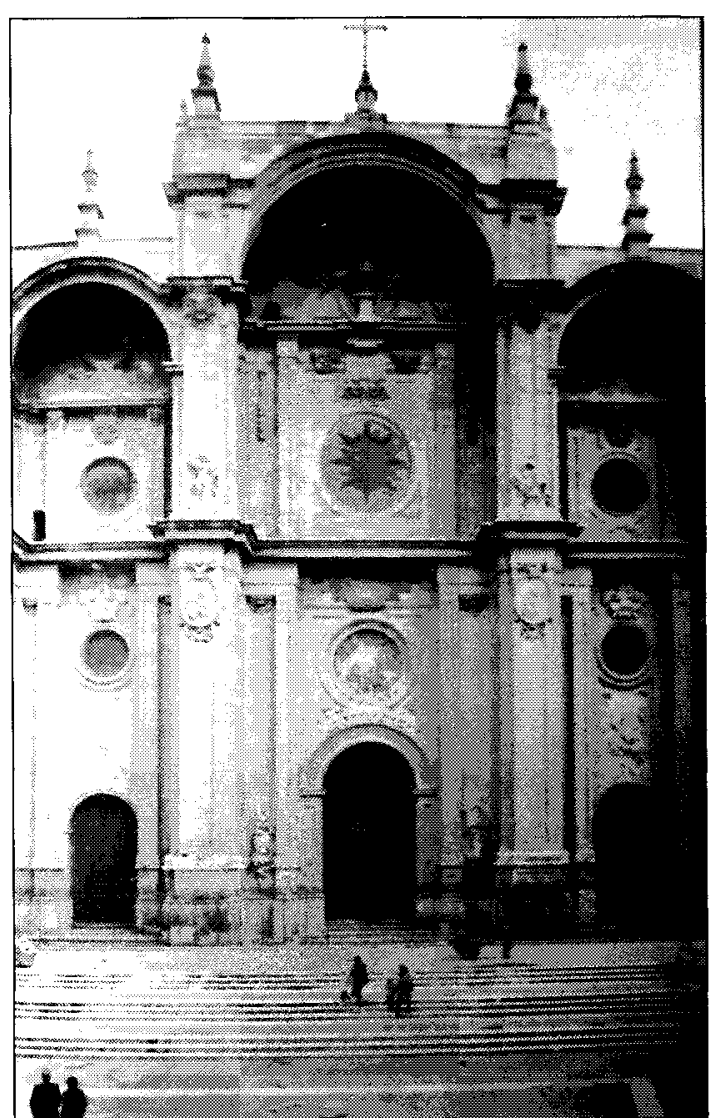

Fig. 14. Portada principal de la Catedral de Granada.

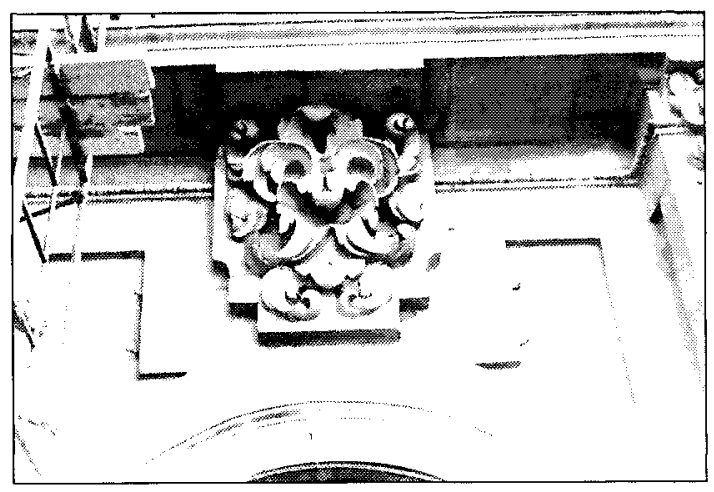

Fig. 15. Detalle de la decoración escultórica. Cartela. Portada principal. Catedral de Granada.
Las placas recortadas y las valientes y estáticas pilastras-machones no son bien interpretadas por las esculturas de los franceses, que en lugar de coincidir en el lenguaje de sus contenidos plásticos y proporciones a veces lo contradicen y distraen. Ya propuse en 1979 su lectura como el gran retablo final de Cano, como obra en todo arquitetónica y de cierre, indicando entonces lo acertado y lo menos afortunado de estas relaciones interartísticas, insistiendo en la importante función plástica que cumplen los propios elementos decorativos vegetales de claro concepto escultórico ${ }^{18}$.

Ese Cano polivalente, practicando la transgresión de las divisiones separadoras de los géneros artístico-plásticos y fundiendo en una propuesta escultórica las dimensiones propias de lo pictórico, se hace aún más frecuente en sus prácticas como escultor-pintor, como ya vimos en su etapa sevillana, incluso cuando realiza el mismo tema en ambas artes. Es entonces cuando se consuma, de manera más evidente y feliz, este maridaje entre las dos artes plásticas. Los préstamos mutuos producen algo parecido a los realizados por la poesía a la pintura o viceversa, pero siempre alcanzando el nivel de lo distinto y diferente, porque a cada lenguaje artístico corresponde su específica manera y forma, ya que la pintura es una representación y la escultura una presencia real, anhelando ambas siempre el propio encuentro. $Y$ de esta manera se adquiere una nueva dimensión, que a nivel teórico hace que las relaciones interartísticas se busquen teóricamente ya en Aristóteles o incluso en Platón, y no sólo en el ut pictura poesis de Horacio. Pero la polémica es indisociable de una permanente teoría de la mímesis, incluso en períodos como este que viven Cano y Montañés entre el naturalismo incipiente y el idealismo como reacción contraria, transición en la que se está cuestionando las convenciones realistas. Históricamente la comparación de las artes entre sí ha ido acompañada de la comparación entre el tipo de conexión que mantiene cada una de ellas con la naturaleza y la realidad.

Como sabemos, en no despreciable medida la comparación ha tomado el cariz de una competencia por decir cuál de las artes es más idónea para la imitación de su objeto. Como afirma el norteamericano Mitchell, en relación con la polémica entre pintura y poesía:

\footnotetext{
18 Sánchez-Mesa Martín, D., «La portada principal de la Catedral de Granada como el gran retablo barroco de Alonso Cano». Estudios sobre Literatura y Arte III. Homenaje al Profesor Orozco Díaz. Granada, 1979, pp. 307-322.
} 
«La historia de la cultura es en parte el relato de una dilatada pugna por la dominación entre signos pictóricos y lingüísticos, reclamando cada uno para sí ciertos derechos de propiedad sobre una «naturaleza» a la cual sólo él tiene acceso».

Así es nuestro caso, en el que la escultura y la pintura, que aún y a pesar de ser «artes hermanas» (visuales y matéricas), se revelan a menudo como rivales, celosas de su relación con el mundo real. Es el concurso del «Paragone» de Leonardo, en el que el artista en el papel de Paris se decanta a favor de la pintura, mientras que Lessing, más salomónico, resuelve asignando a cada arte un objeto propio. Pero, como afirma Antonio Monegal en la obra citada, este debate del que nadie parece salir convencido no se agota nunca, por muchos argumentos que se aporten en contra de la posibilidad misma de comparar ambas artes — para él la pintura y la poesía y para nosotros aquí la escultura y la pintura-. Porque lo que está en juego, lejos de ser una discusión bizantina (aunque, si ahondamos en el trasfondo teológico del conflicto entre iconoclastas e iconodulas, sí hay algo de eso y sí que hay matices y diferencias entre las imágenes pintadas y las presentes corpóreamente), es toda una teoría de la representación y de la recepción, a partir de la cual se define la naturaleza y función del arte.

Distinguir entre lo propio de cada lenguaje y lo apropiado, pone en la palestra la mayor o menor idoneidad del tema representado. Es, por ejemplo, el caso para Cano de la representación del movimiento en la escultura del Niño Jesús Nazareno, que camina con la cruz a cuestas, de la Cofradía de San Fermín de los Navarros de Madrid (h. 1657-60), en madera policromada, y la propia escena de la Asunción de la serie de la Catedral granadina (1662), o el lienzo de la Virgen del Rosario de la Catedral de Málaga (1665-66), con los grupos de angelillos portadores de atributos o envueltos en dinámicos movimientos entre las ingrávidas nubes del trono. De la realidad material y concreta de lo escultórico, tangible y cercano, - al que se le ha mermado en apariencia su cualidad y dimensión estática, precisamente con las propias notas pictóricas de la talla suelta y del color en las carnaciones y túnica-, se pasa a la fantasía de movimiento e ingravidez representada en el lienzo, pero sin que los propios volúmenes pintados renuncien a sus referencias y cualidades plásticas de apariencia escultórica, con soluciones que precisamente, sin dejar de ser apropiadas, no son en esencia propias del lenguaje que las utiliza como verdaderas metáforas propias.

Quizás, por ello, de todas las esculturas atribuidas a Cano sea ésta -el Niño Jesús nazareno-, en cierta manera, la más singularmente pictórica. Además, el primor con el que está hecha la policromía incide en la valoración de la obra como algo metafórico y también como algo concebido y realizado para su contemplación cercana. El dibujo de la túnica pintada en dos tonos, imitando follajes y con toques de oro a pincel, se enriquece con pequeños pliegues y medallones, en los que se representan asuntos bíblicos miniados, todos referidos al tema de la pasión, como prefiguraciones, y a la salvación por la redención, como son la serpiente de bronce, Isaac camino del sacrificio, Jacob en lucha con el ángel y otros. Esta perfección con la que interviene el pincel se iguala al trabajo de las gubias, que a veces se complementa con detalles y filos en telas encoladas para alcanzar más veracidad y mayor sensación de movimiento. Tanto el modelado de la cabeza, de sueltos y blandos mechones, como el fino dibujo de la boca y ojos, así como las gordezuelas manos, queda resaltado por una profunda compenetración con la policromía y los contrastes de calidades con la rugosidad de la superficie de la cruz arbórea o la ilustrada superficie del globo terráqueo, sobre el que, como punto de apoyo casi inestable, coloca su pie de caminante.

De no ser a Cano ¿a quién podría atribuirse esta preciosa talla policromada? Ni las obras conocidas de Salvador Carmona, ni las de Manuel Pereira se acercarían más que a lo hecho por Cano tras su primera estancia granadina, en la que este intimismo e inspiración alcanzan 

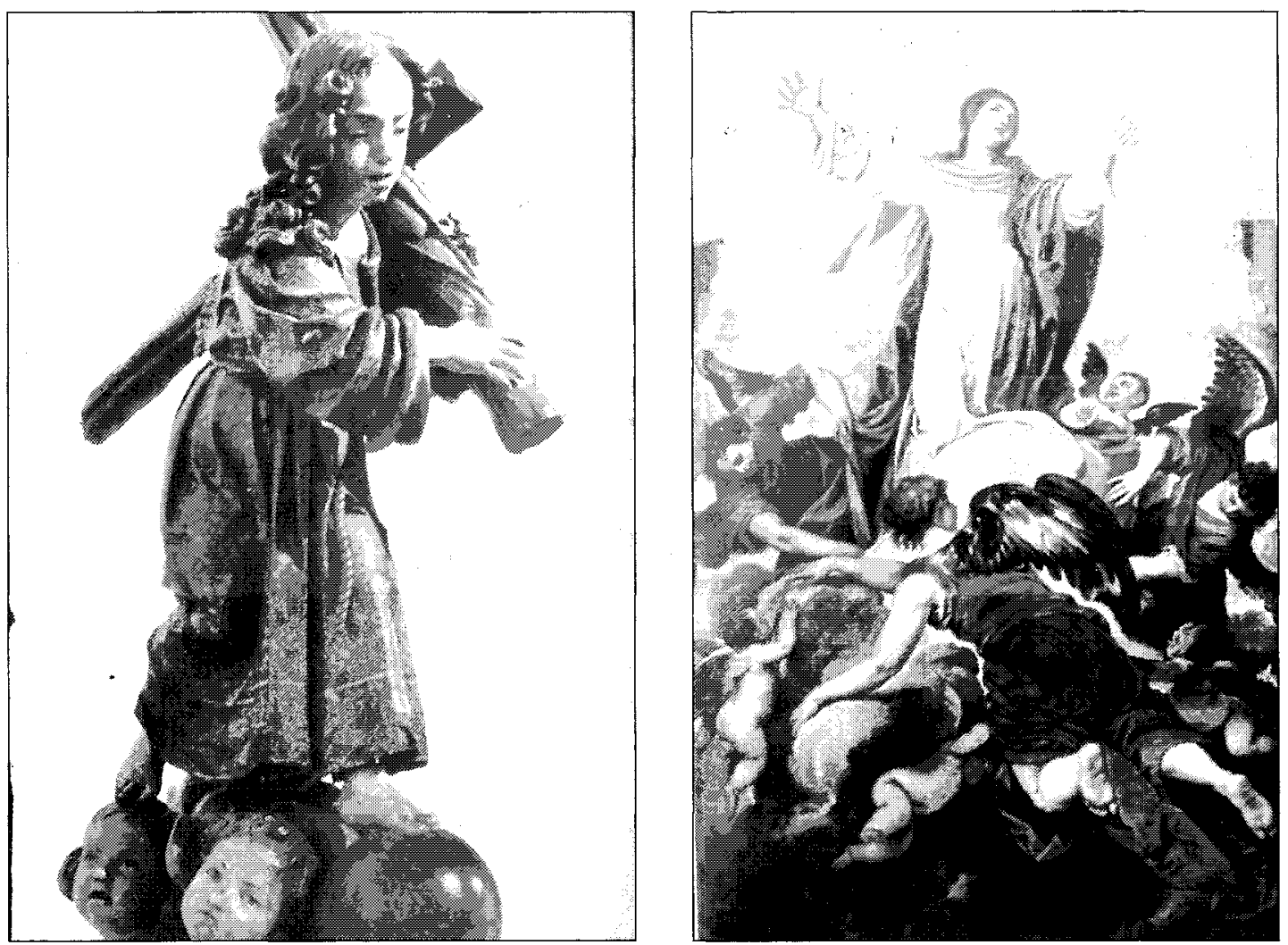

Fig. 16. Niño Nazareno. Cofradía de S. Fermín de los Navarros, Madrid.

Fig. 17. Asunción de la Virgen. De la serie de la Vida de la Virgen. Catedral de Granada.

su zénit, en todo también diferente a la escultura napolitana y genovesa con la que en ocasiones se ha querido relacionar.

Y esta relación entre lo escultórico y lo pictórico en Cano se hace ya propia y definidora de su estilo individual, incluso en sus dibujos, tal como ya anotábamos y ahora vemos, por ejemplo, en los referidos al Niño Jesús bendiciendo y con el globo del mundo en la mano, de la Biblioteca Nacional, de dudosa atribución al artista, o al grupo de Jesús Niño y San Juanito, del Museo del Prado, ya como proyecto uno para hacerlo en escultura —el pequeño Niño Jesús, de colección particular malagueña, que dimos a conocer en 1968 - o para la pintura el otro. El tamaño pequeño de la figurita, tallada en madera y primorosamente policromada, la convierte en singular (mide $11 \mathrm{~cm}$.), aunque los rasgos de su modelado son en todo propios del estilo del racionero. Fuera de su autoría se nos hace difícil fijar atribuciones con mayor lógica y razón ${ }^{19}$.

Pero también sobre lo equivalente se trata en estas propuestas comparativas, aunque sin olvidar nunca las diferencias propias para cada una de ellas. Por supuesto hay que aceptar que la diferencia es compatible con la analogía. Buen ejemplo para experimentar esta afirmación es el estudio comparado del Santiago del Museo del Louvre, proveniente del retablo de Santa Paula de Sevilla (h. 1635-37) (pintura en todo propia de un gran maestro pintor experimentado en el oficio, pero también demostrativa de su conocer y saber hacer escultura) con la impresionante cabeza de San Pablo del Museo catedralicio de Granada, ya de su última época (h. 166067). Aquí las gubias parecen pintar y allí los pinceles parecían tallar. Y no es ya sólo la seme-

${ }^{19}$ Sánchez-Mesa Martín, D., La técnica de la policromía en la escultura granadina. Granada, Universidad, 1972. p. 147. 

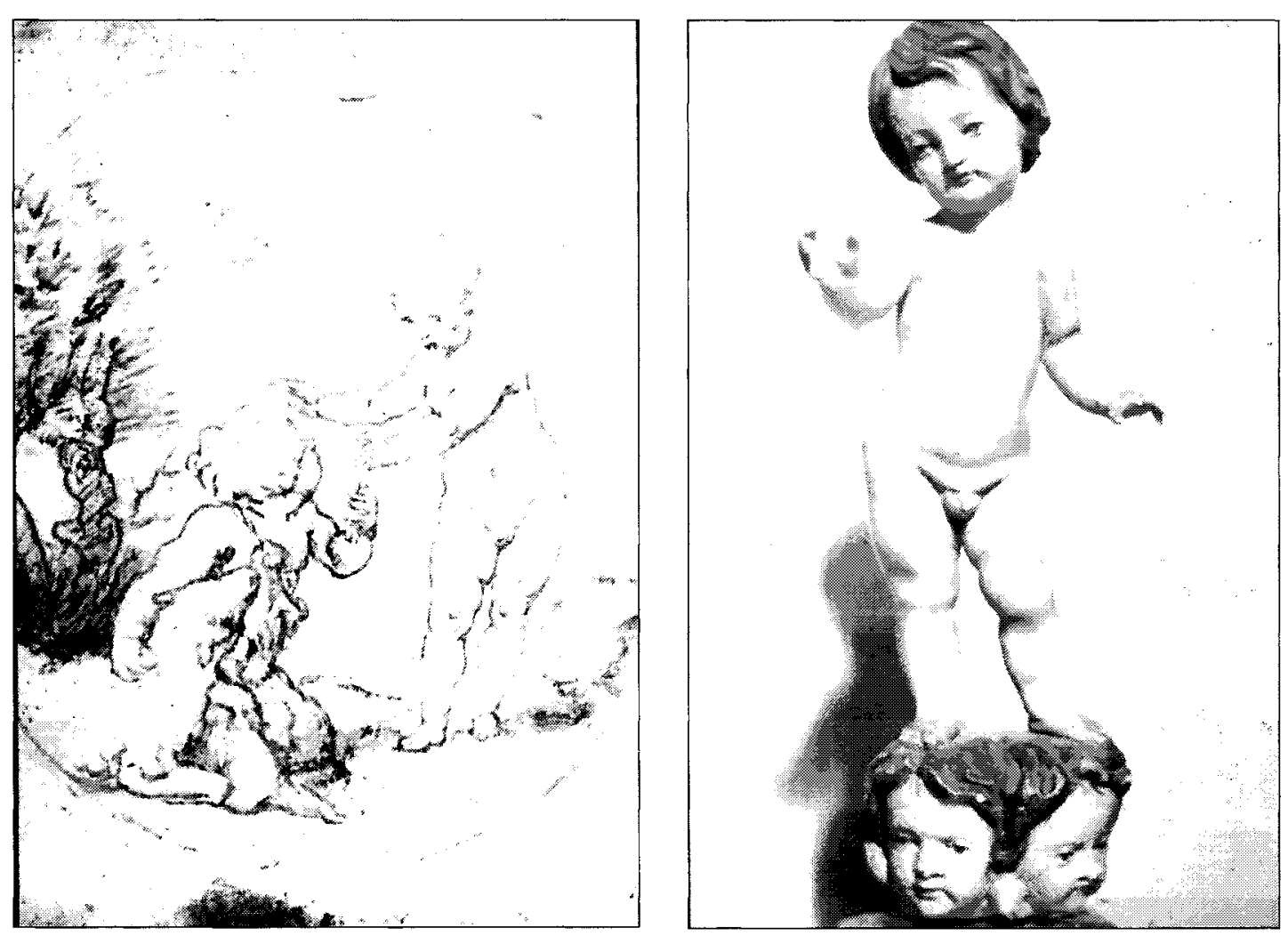

Fig. 18. Dibujo del Niño Jesús y S. Juanito. Museo del Prado.

Fig. 19. Niño Jesús bendiciendo. Colección particular, Málaga.

janza o repetición de un mismo parecido tipo humano o modelo. La cuestión es más esencial e importante, ya que hace referencia a conceptos de expresión y creación plástica. ¿Se podría entender el alcance estético de esta obra, de alto brío y calidad escultórica, prescindiendo del color y de su dimensión pictórica? Imposible. Las mismas aristas del corte de las gubias sobre la madera parecen equivaler al relieve de la pincelada pastosa sobre el lienzo. Las cabezas del San Pedro y el San Pablo del retablo de Lebrija marcan el punto medio entre ambas versiones del mismo tema y lenguaje plástico.

Otro tanto podríamos ver con el tema de la Inmaculada, capítulo central de su producción, empezando más que por sus primeras versiones, tan cercanas al arte de Montañés y a las que ya nos referimos de pasada, por la que fue realizada hacia 1655 como remate para la urna del facistol, versión en lo escultórico más concentrada y depurada incluso que la triunfante y retadora de la Diputación de Álava, hoy en el Museo de la Catedral de Vitoria ${ }^{20}$. La versión pictórica del modelo escultórico concluye, tras la monumental de la serie de la Vida de la Virgen de la Catedral y la perteneciente a los herederos del Conde de las Infantas, en la del Oratorio de la Sala Capitular (1660-67), en todo pintura de avanzada paleta, donde la estética de un rococó a la española la separa de las anteriores. En ella los angelillos y querubines repiten y definen también otro de los temas en los que el arte de Cano, en sus facetas de pintor y escultor, más se define y singulariza.

Pero, sin duda, de todas las versiones hechas en pintura y las primeras en escultura, es en la ideada para el facistol de la Catedral granadina donde Cano consigue no sólo la interpreta-

${ }^{20}$ Azcárate Ristori, J. M." de, «La Inmaculada de Cano de la parroquia alavesa de Berantevilla». Vitoria, 1963. 

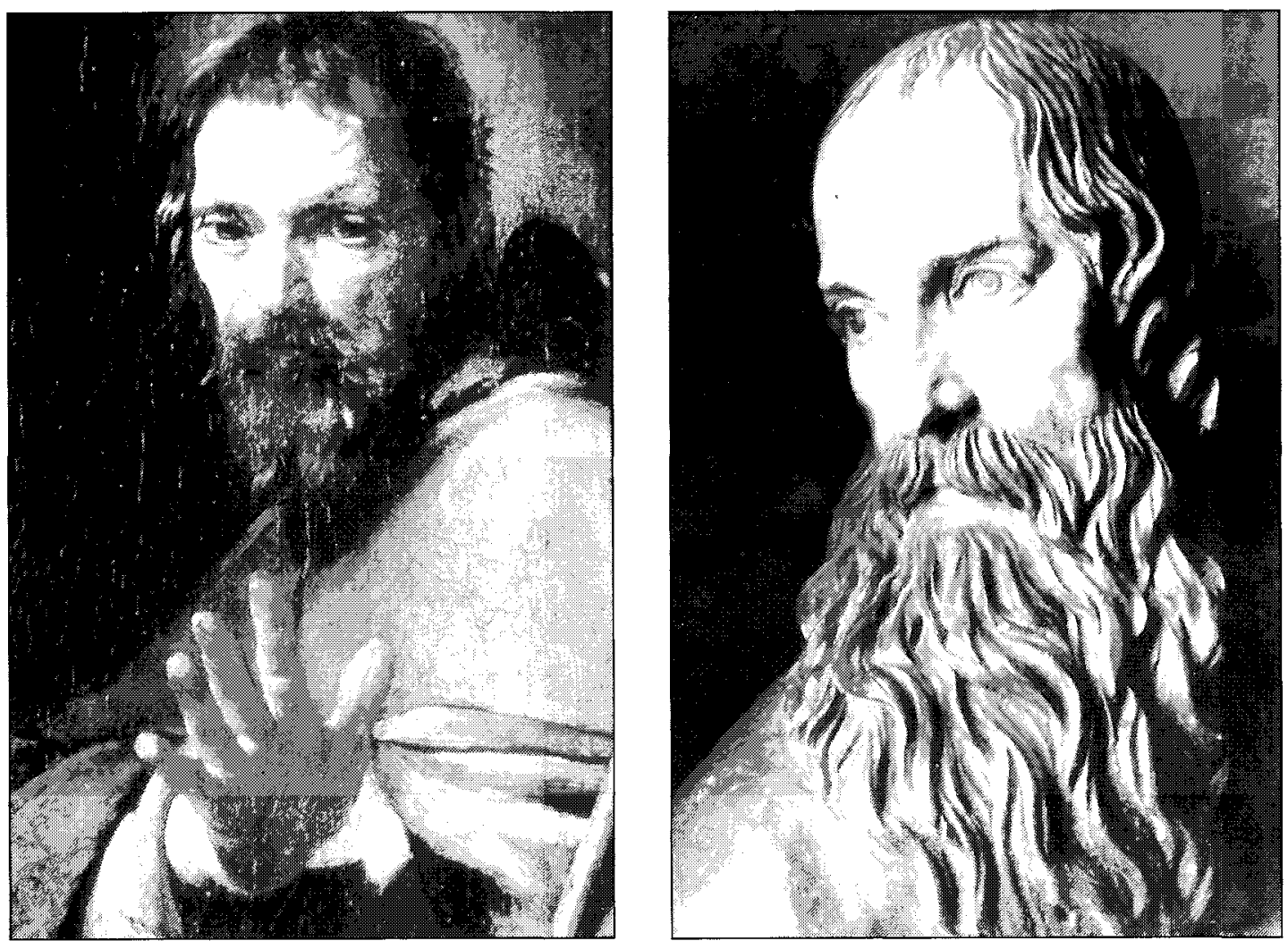

Fig. 20. Santiago (detalle). Museo del Louvre.

Fig. 21. San Pablo. Museo de la Catedral de Granada.

ción del tema, sino la más perfecta y equilibrada compenetración entre lo escultórico y lo pictórico. Hasta incluso las proporciones de su tamaño suponen un gran acierto. Cuidada en todos sus perfiles, significa también un feliz hallazgo la propia dinámica compositiva por la que los volúmenes y los ritmos plásticos, cóncavos y convexos, sin dejar de ofrecer la serenidad dominadora de la verticalidad, consiguen la emoción de lo ingrávido y casi etéreo. El profesor Martín González, refiriéndose a ella, escribe:

«Es raro encontrar en nuestro pasado artístico un caso de tal compenetración de la escultura y la pintura, intercambiando sus elementos» ${ }^{21}$.

Todos estos valores formales, como siempre en el Cano profundo, encierran hondos sentimientos íntimos y contenidos espirituales. Esto es lo que impulsa a historiadores tan poco dados a los elogios fáciles de halagadoras palabras y términos, como fue el caso de D. Manuel Gómez-Moreno Martínez, a describirla de este modo:

«Una pureza virginal que aunaba candor de niña y gravedad de mujer, perfección plástica y soberanía espiritual; esbeltez de palmera, recato de torre marfileña, blancura de azucena envuelta en al azul del lirio, los cielos a sus pies y la adora-

\footnotetext{
21 Martín González, J.J., «Comentarios al tema de la lnmaculada en Alonso Cano y una escultura inédita granadina». Centenario de Alonso Cano en Granada. Estudios. Granada, 1969, p. 227.
} 

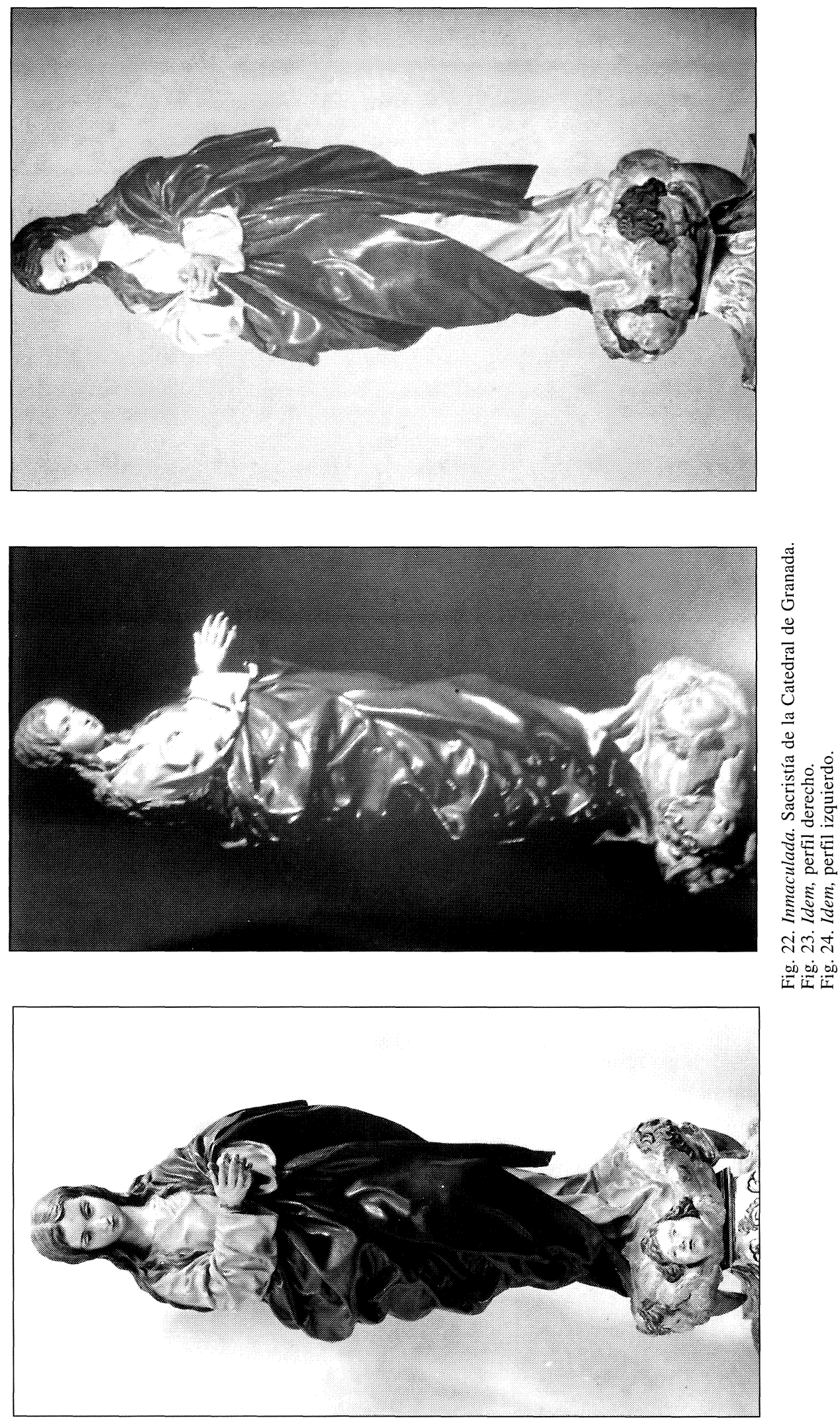

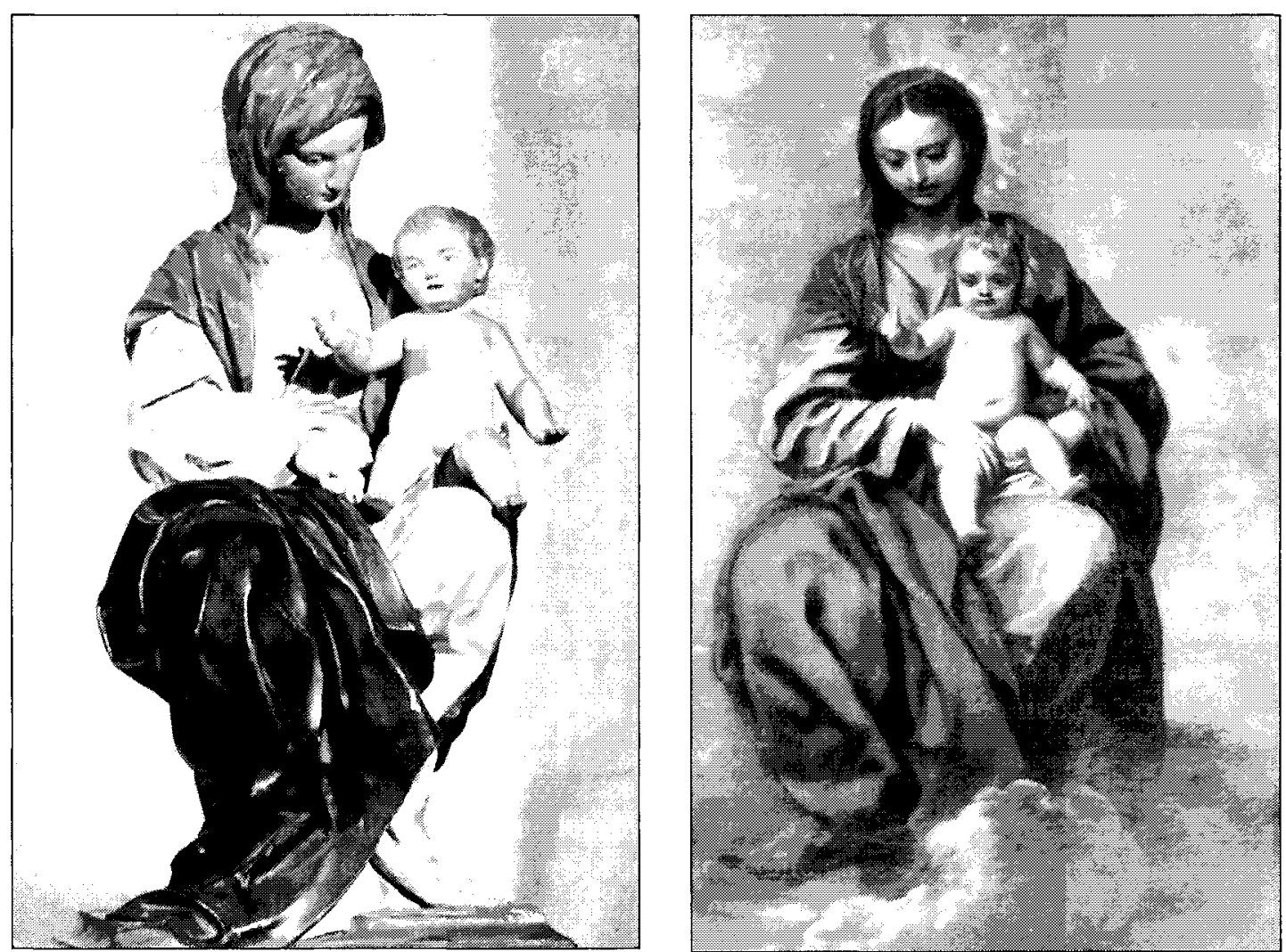

Fig. 25. Virgen de Belén. Museo de la Catedral de Granada.

Fig. 26. Virgen de Belén. Curia eclesiástica. Granada.

ción estática de manos y rostro... Cano envolvió su Inmaculada en un torbellino de curvas, como nube que hace impenetrable la estructura corporal, dejando sólo a la vista rostro y manos, los órganos libremente expresivos» ${ }^{22}$.

Cerramos estos ejemplos, en los que las analogías entre las versiones escultóricas y pictóricas nos ofrecen un Cano de una singular sensibilidad y de un personalísimo estilo en nuestro barroco, con una serie de obras de su última etapa granadina, en las que Cano escultor funde de manera singular su amplia y refinada maestría de artista polifacético. Y lo hace con frecuencia en el campo de la escultura, atendiendo con abundancia de matices tanto su capacidad para materializar lo íntimo y cercano en obras de pequeño tamaño, trabajadas con primor, como lo monumental y amplio en tallas de tamaño mayor que el natural, siempre cuidadas en todos sus perfiles y completadas con ajustada policromía.

En casos esta complicidad del Cano escultor y el Cano pintor se materializa en distintas versiones - la escultórica y la pictórica - de un mismo tema, como ocurre en el lienzo de la Virgen de Belén de la antigua Curia, que dimos por perdido tras el desgraciado accidente del incendio que destruyó gran parte de las cubiertas y entreplantas del edificio en 1982. Ennegrecido por el humo y tostada en parte la capa pictórica por el calor del fuego, pensamos que era irrecuperable. La meritoria limpieza y restauración a la que se sometió en el antiguo Instituto Nacional de Restauración en Madrid hizo posible el verdadero milagro. Desaparecidas las

22 Gómez-Moreno Martínez, M., «Alonso Cano, escultor. Archivo Español de Arte, VI (1926), p. 199. 

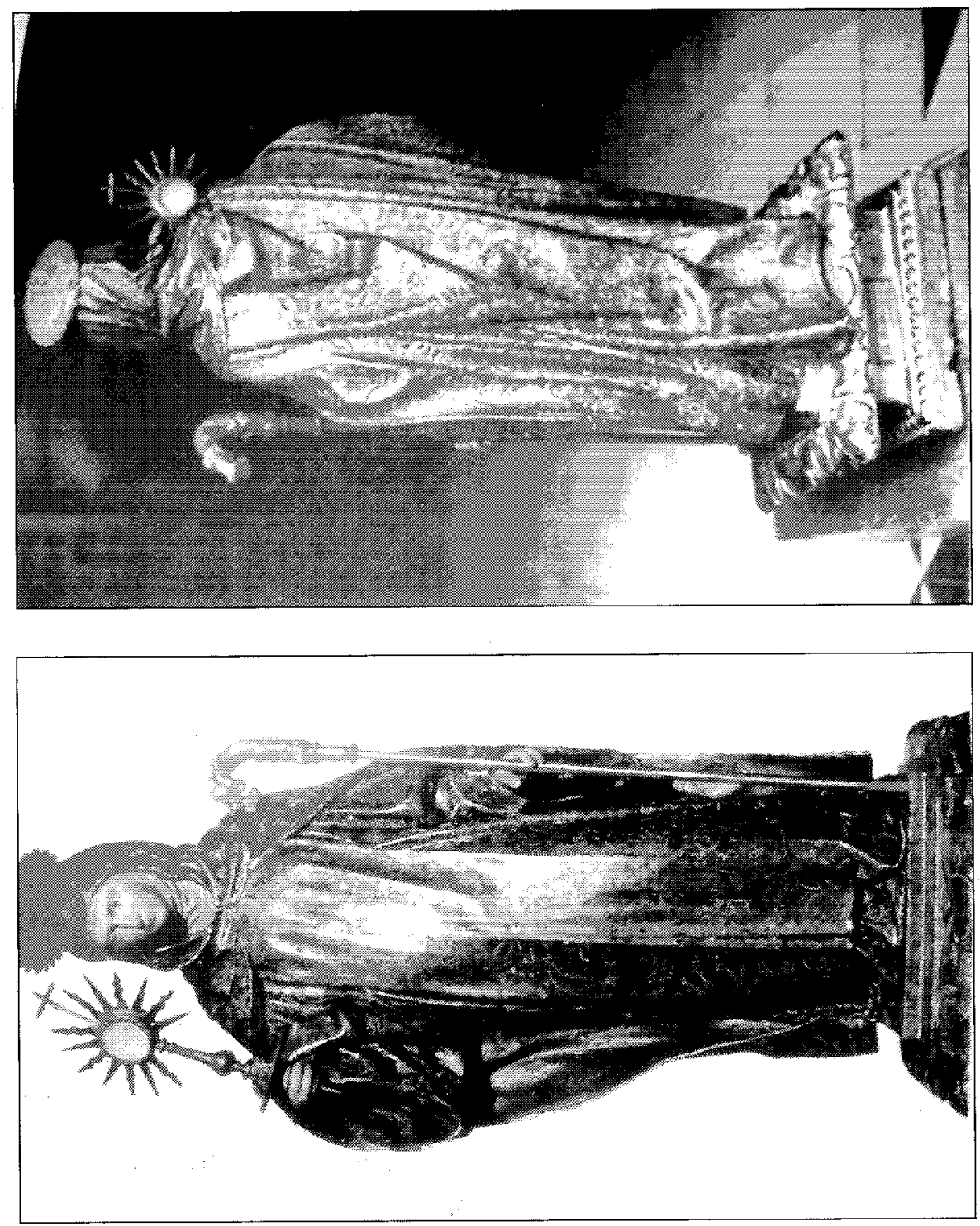

苞

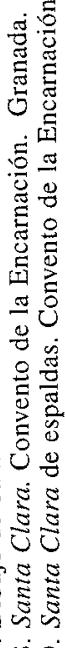

तथ่

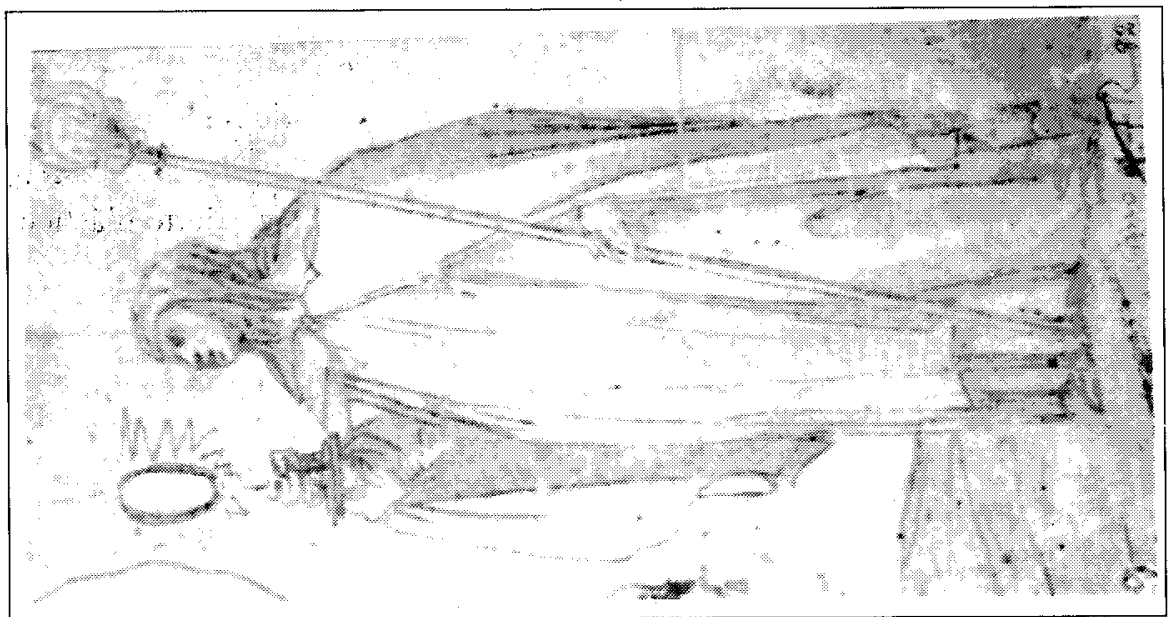

它 
ampollas y reentelado el lienzo, hoy es, sin lugar a dudas, uno de las más destacadas y bellas obras de nuestra pintura barroca española de tema mariano.

Su estudio comparado con la escultura de la Virgen de Belén que Cano talló por los mismos años (entre 1660-64), para sustituir en la urna del facistol a la Inmaculada, hoy en la Sacristía de la Catedral, puede significar idónea y expresiva conclusión de esta propuesta de estudio e interpretación del arte de Cano, basado en los análisis comparados de las distintas artes que practicó. Las relaciones aquí establecidas van más allá de la igualdad del tema, al que ya Cano había dedicado espléndidas obras como la Virgen del Lucero del Prado (1646-48), la de la Colección Plandiura (h. 1652), o la Virgen de la leche (h. 1657-60), de la Diputación de Guadalajara. Ciertamente, de todas ellas ésta de Granada es en la que se dan más coincidencias con la versión escultórica. Las dos están realizadas y concebidas con un punto de vista bajo, logrando la elegancia compositiva que el esquema romboidal ofrece y que para lo escultórico lo convierte en ideales volúmenes de remate y terminación para ser contemplada desde abajo. De ahí que Cano haya resuelto con sentida inclinación de la cabeza la composición del grupo escultórico, compuesto por la madre, serenamente pensante, y el hijo. La agrupación de ambas figuras queda inscrita en ritmos cerrados, resaltados acertadamente por la propia policromía, de finos contrastes y de acertadas armonías, y la talla. El plegado del manto y túnica, de intencionado y amplio dibujo, se traduce con paralelas intenciones plásticas en la versión pictórica y en la escultórica, aunque en este caso la insistencia y acierto de lo pictórico en el lienzo supere quizás a la versión escultórica, que en algunos detalles, como el desnudo del Niño, denotan, respecto al pintado, cansancio o la posible colaboración de algún discípulo, aunque reproduciendo modelo de Cano.

Como obra también destacada de esta serie de figuras de pequeño tamaño, está la logradísima Santa Clara del convento granadino de la Encarnación, de 0’66 m. de altura, fechada hacia 1655 y representada solemnemente con la Custodia en la mano derecha y el báculo de abadesa en la izquierda, con manto hasta la base y toca sobre la cabeza. Tallada en madera de cedro con soltura de composición y valentía de plegado y huecos, alcanza sus indiscutibles valores estéticos tanto en el frente como en los perfiles y espalda, donde los ritmos de las siluetas y de los volúmenes funcionan como destacados claroscuros, tal como ya puede apreciarse en el dibujo preparatorio de la misma que se conserva en el Museo del Prado. La obra, guardada en la clausura del convento, se conserva intacta, incluso con su rica y finísima policromía sobre oro y carnación original. Una vez más el primor de la talla encuentra su mejor complemento en la policromía y en las carnaciones del fino rostro.

La elegancia y serenidad del arte del racionero alcanzan en esta pequeña escultura otro de los más significativos y finos ejemplos de su arte. En el rostro se repite el acierto del tipo de la famosa Inmaculada de la Catedral. La posible autoría de Pedro de Mena, a la que se refiere Wethey, no la veo en ninguna parte de sus rasgos y características plásticas. La evidente blandura y alta elegancia de modelado y talla reflejan en todo las manos de Cano. De nuevo la visión que ya el dibujo preparatorio nos brinda nos demuestra la intención y acierto plástico con el que se concibe la obra ya desde el boceto ${ }^{23}$.

En la misma línea de rotunda corporeidad se desarrollan las también pequeñas versiones del San Diego de Alcalá, hoy en el Instituto Gómez-Moreno de Granada, o la del San Antonio de San Nicolás de Murcia y la más pequeña también del referido Instituto granadino. El San Diego de Alcalá, de 0'66 m., está tallado en pino y en taco de madera aparte la cabeza. De nuevo la aguda sensibilidad de Cano ha sabido armonizar siluetas y contornos en ritmos cerrados y en todos sus perfiles con serenidad y elegancia en las proporciones. La profundidad ex-

${ }_{23}$ Orozco Díaz, E., «Una imagen de Alonso Cano olvidada». Arte Español (1968-69). 

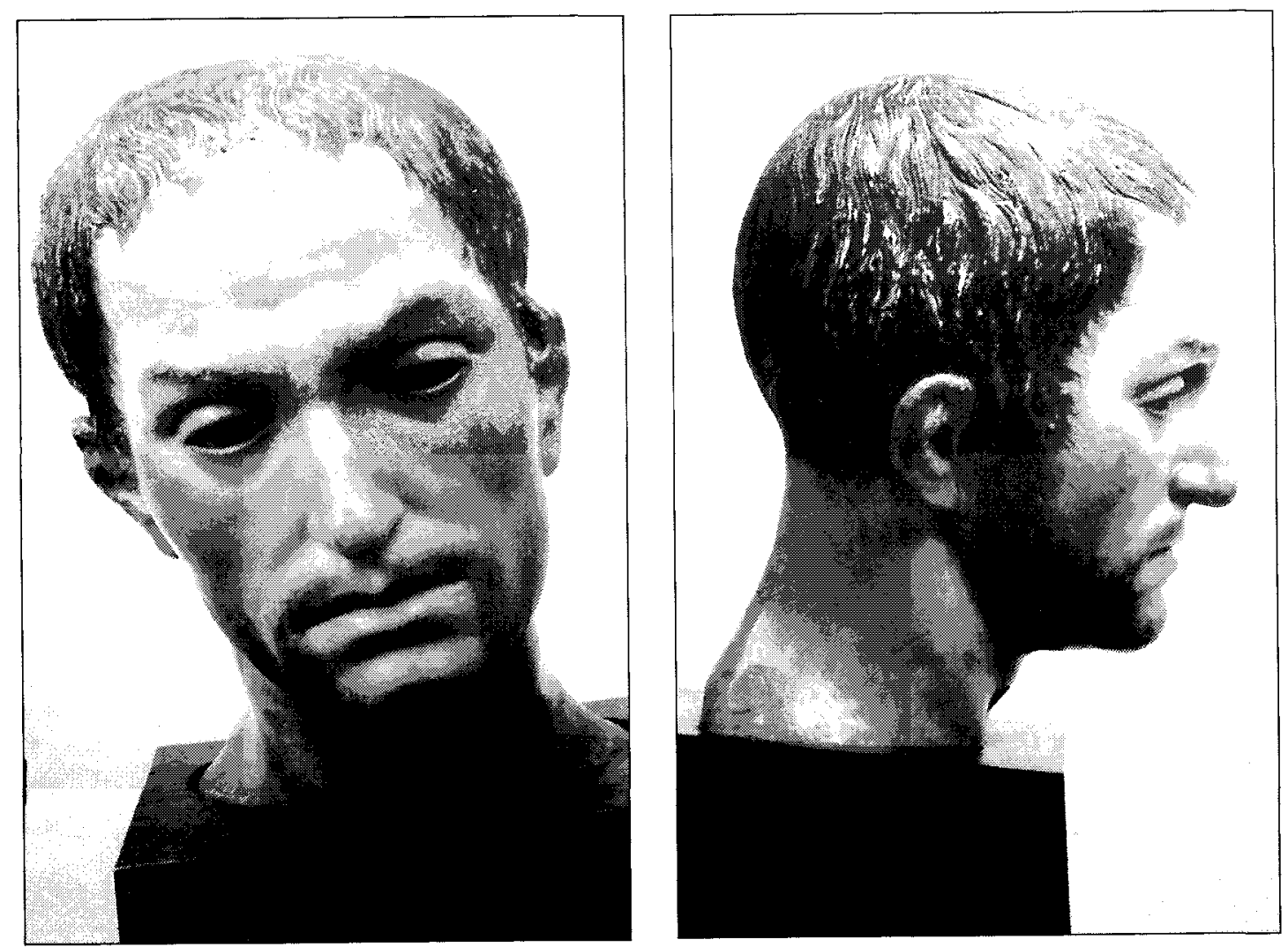

Fig. 30. Cabeza de San Juan de Dios. Museo de Bellas Artes, Granada.

Fig. 31. Cabeza de San Juan de Dios, perfil. Museo de Bellas Artes, Granada.

presiva del rostro, siempre pensante, se concentra con especial sentimiento en la mirada profunda de los ojos de cristal. Esta sobriedad y definición plástica del conjunto total y del plegado se consigue en parte por una policromía austera, imitando la estameña del hábito franciscano, que el santo recoge frontalmente con sus manos para guardar las limosnas que dará a los pobres y que se convertirán milagrosamente en flores, acción y suceso que justifican su ensimismada y pensante mirada. Todo está dicho y expresado como escultura exenta, total y plena en todos los perfiles, tanto los laterales, de vigorosas diagonales, como en el frontal y en el de la espalda.

En la misma línea y de acuerdo con los mismos criterios plásticos, pero incorporando ahora el contraste y riqueza escultórico-pictórica del Niño Jesús desnudo, habrá que recordar las referidas versiones del San Antonio. El de Murcia, que apenas alcanza los 0’47 m., tiene en la base una inscripción sobre placa clavada en la peana, en la que se lee: «A devoción del Ilmo. Sr. D. Alonso Antonio de S. Martín, abad de Alcalá. El rzo. Alonso Cano Fact. Granada». Sobre el idealismo espiritualizante del conjunto sobresale una clara naturalidad, tanto en el plegado del hábito, apenas interrumpido por algún doblez en la caída, como en el propio desnudo del Niño, sostenido entre las manos con blancos pañales, y extendiendo los brazos como para poder contemplarlo en su totalidad, que de manera expresiva parece cogerse al filo de la capa del Santo. La cabeza de éste es todo un compendio de finura y expresión de contenida emoción espiritual. Aún más pequeño, apenas alcanza los $29 \mathrm{~cm}$., es el San Antonio del Instituto Gómez-Moreno (h. 1660), representado igual que el anterior, pero acercando el Niño casi al rostro, como en un arrobado abrazo de un idílico diálogo místico. 

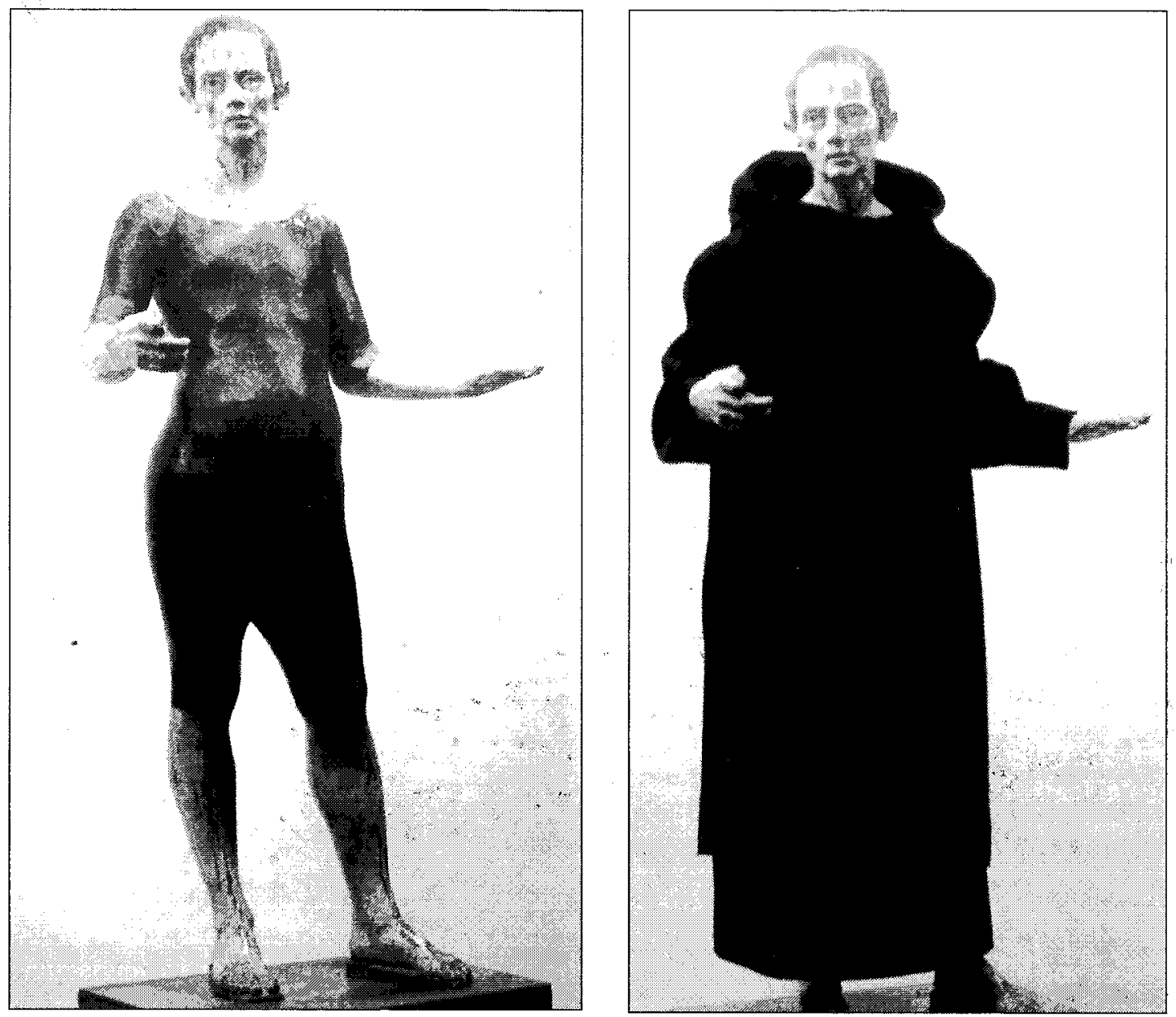

Fig. 32. San Juan de Dios (figura para vestir). Colección particular, Granadà. Fig. 33. San Juan de Dios. Idem.

En estas figuras de pequeño tamaño, en todo superadoras de la modalidad de las figuras napolitanas, Cano nos ofrece al final de su vida aspectos esenciales de su intimidad espiritual, serenamente recreada, profundizando de manera equilibrada en la forma y en el contenido. Pero esto no significa incapacidad para concebir y trabajar la escultura a tamaño natural o con criterios monumentales. La profunda expresión, el amplio y seguro modelado y el dibujo de la cabeza de San Juan de Dios del Museo de Bellas Artes de Granada es singular muestra de esto que afirmamos. Publicada en 1926 por Gómez-Moreno Martínez, apunta la posibilidad de que perteneciera al antiguo convento de la Victoria, donde el santo fue primeramente sepultado y donde recibía culto. Pasó al Museo tras la recogida de imágenes de los conventos cuando la exclaustración.

Según se deduce por el acabado de la talla del cuello perteneció a una imagen de vestir, sin que este destino aminore en absoluto la calidad artística de la cabeza, que resulta, sin lugar a dudas, una de las más afortunadas representaciones de este llamado Santo de la Caridad, tan arraigado en la historia de la ciudad de Granada. Una vez más la profundidad y agudeza del arte de Cano alcanza una ejemplar y única versión iconográfica plena de serenidad de espíritu y hondura de pensamiento. Nada encontramos aquí del arte de Pedro de Mena, como apunta Wethey, que en sus versiones del tema camina por otros senderos. Bien se puede hablar de toda una categoría de retrato romano que llega desde el naturalismo a la idealidad. La policromía 

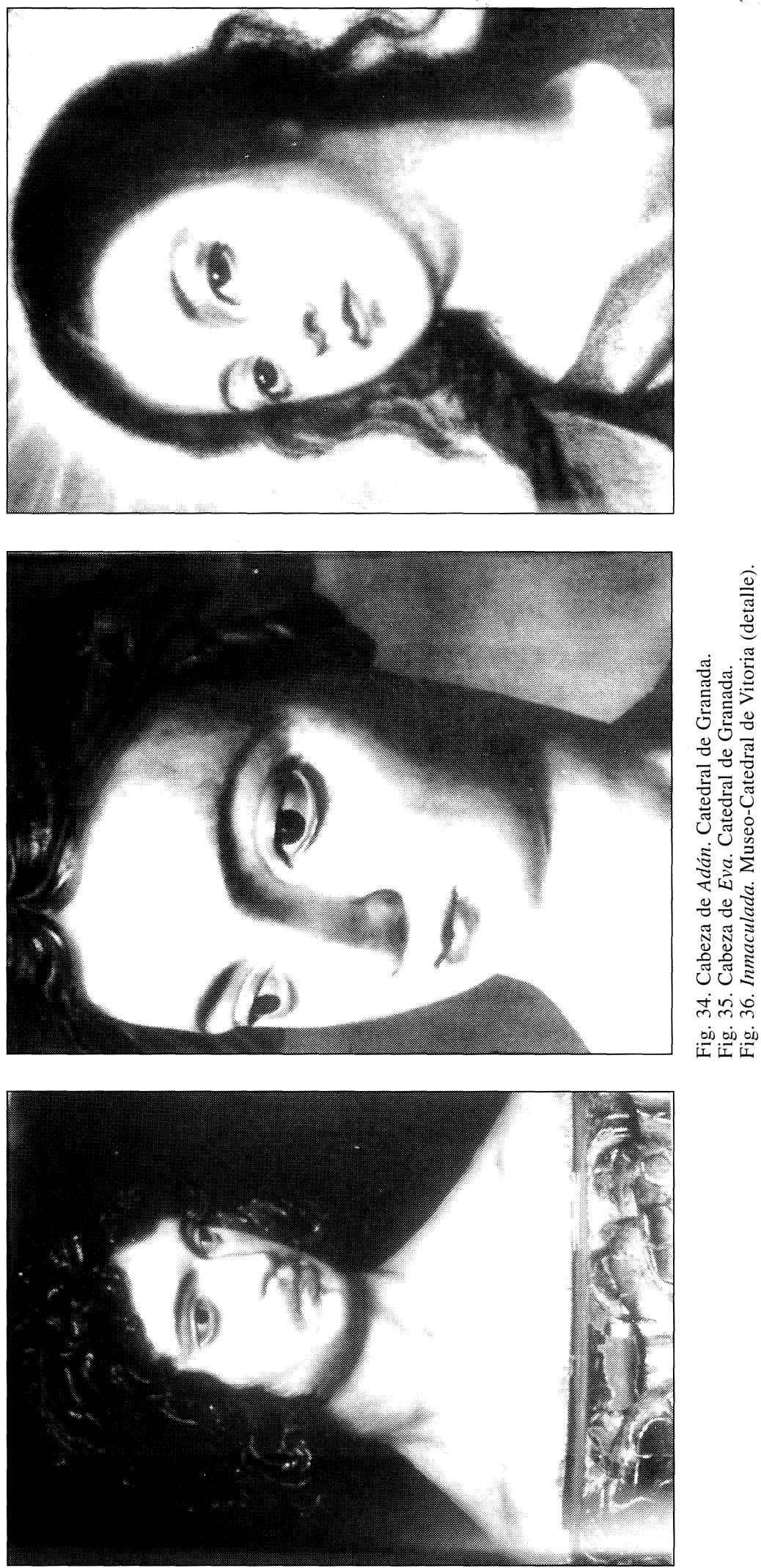
ennoblece la forma y la relaciona cercanamente con cabezas pintadas en los lienzos de esta etapa como su San Juan de Capistrano del mismo museo. Coincidiendo con este espíritu y tipo, encontramos en colección particular granadina una escultura de pequeño tamaño, tallada al completo, pero hecha para vestir. Todo en ella, pero en especial la cabeza, nos lleva a Cano y como tal la dimos a conocer en $1984^{24}$.

Los dos bustos de Adán y Eva, de tamaño mayor que el natural (0’64 m.), que talla Cano en madera para los tondos de la Capilla Mayor de la Catedral, nos ofrecen expresivos y valiosos testimonios de la personalidad artística del Cano escultor en su etapa final, que de manera tan atractiva nos hacen recordar los bustos del Bernini, aunque aquí el naturalismo y blandura que aporta la policromía, realizada, según se acepta, por el pintor Juan Vélez de Ulloa, los haga más cercanos y vivientes.

En contraste con estas obras Cano realiza, posiblemente en el taller de Pedro de Mena - que hasta hacía poco era el de Alonso de Mena-, cuatro grandes figuras destinadas al crucero de la iglesia del antiguo Convento del Santo Ángel, que él había proyectado como arquitecto. Realizadas en madera, con 2'03 m. de altura, se concibieron para ser vistas desde abajo, circunstancia que justifica muchas de las soluciones compositivas y la amplitud de plegado. Se viene aceptando que fueron talladas por Pedro de Mena según modelos del racionero. Si esto fue así, sobre todo tres de ellas — San Diego de Alcalá, San José y San Antonio- se hicieron reproduciendo con fidelidad dichos modelos, siendo muy posiblemente obras directas del propio Cano, tal como su calidad demuestra, las cabezas de los santos y los dos desnudos del Niño que portan el San José y el San Antonio. Su acentuado naturalismo, blandura de modelado y, fundamentalmente, su policromía son en todo de Cano, como bien pueden deducirse de las comparaciones con las obras realizadas por Mena sin los modelos de Cano, incluso el bello y perdido Niño de la Virgen de Belén de Santo Domingo de Málaga. En todos ellos está presente un mayor naturalismo, pero representado más allá de la mera copia directa del natural, al poetizarlo con rasgos de grandeza y de íntima y emocionada contemplación. También, una vez más, la paleta de las carnaciones y la policromía de los hábitos modela los volúmenes y resalta las siluetas y los perfiles.

Caso distinto es la figura del Santo Angel de la Guarda, que Cano hizo para la portada de la iglesia del citado convento, esculpiéndola en mármol blanco sin lugar a dudas con la colaboración de los Moras, tal como lo denotan evidentes titubeos en el plegado de los vestidos del ángel y las formas más envueltas y menos definidas de las cabezas. No obstante, la belleza de los modelos y la segura dirección y corrección del maestro hacen de la obra pieza deliciosa y en todo propia del genio del racionero. Es un error prescindir de las alas, que seguramente el original tuvo y, aunque de madera y de ejecución posterior, armonizan y acentúan los elegantes ritmos y compensaciones de volúmenes que el grupo escultórico posee.

Serán pues estas series de obras realizadas en Granada, alternando con su importante producción pictórica, las que más hondamente reflejan la sensibilidad de su temperamento de escultor. En ellas vierte lo mejor de su inspiración, desenvolviendo ahora, completamente lejana la influencia de Montañés, su propia y original personalidad escultórica, ya genialmente iniciada con los trabajos de Lebrija.

El concepto que Cano tiene de la forma y el volumen revelan, como ya apunté, una vocación fundamental de escultor, que en nada contradice su apasionamiento por el color con el que traduce y acentúa la propia elegancia de los volúmenes escultóricos. Sus formas, de ritmos cerrados, se traducen y completan con la pintura. En esta época de madurez la policromía de las esculturas se hace cada vez más pictórica, equilibrando la armonía entre forma, volumen y color.

${ }^{24}$ Sánchez-Mesa Martín, D., «Contenidos y significaciones de la imaginería barroca andaluza», Cuadernos de Arte, XVI (1984), pp. 283-308; «San Juan de Dios de Alonso Cano», en Imágenes de Sun Juan de Dios. Granada, 1995, pp. 124-127; «¿San Juan de Dios de Alonso Cano?», en Imágenes de San Juan de Dios, ob. cit., pp. 128-130. 

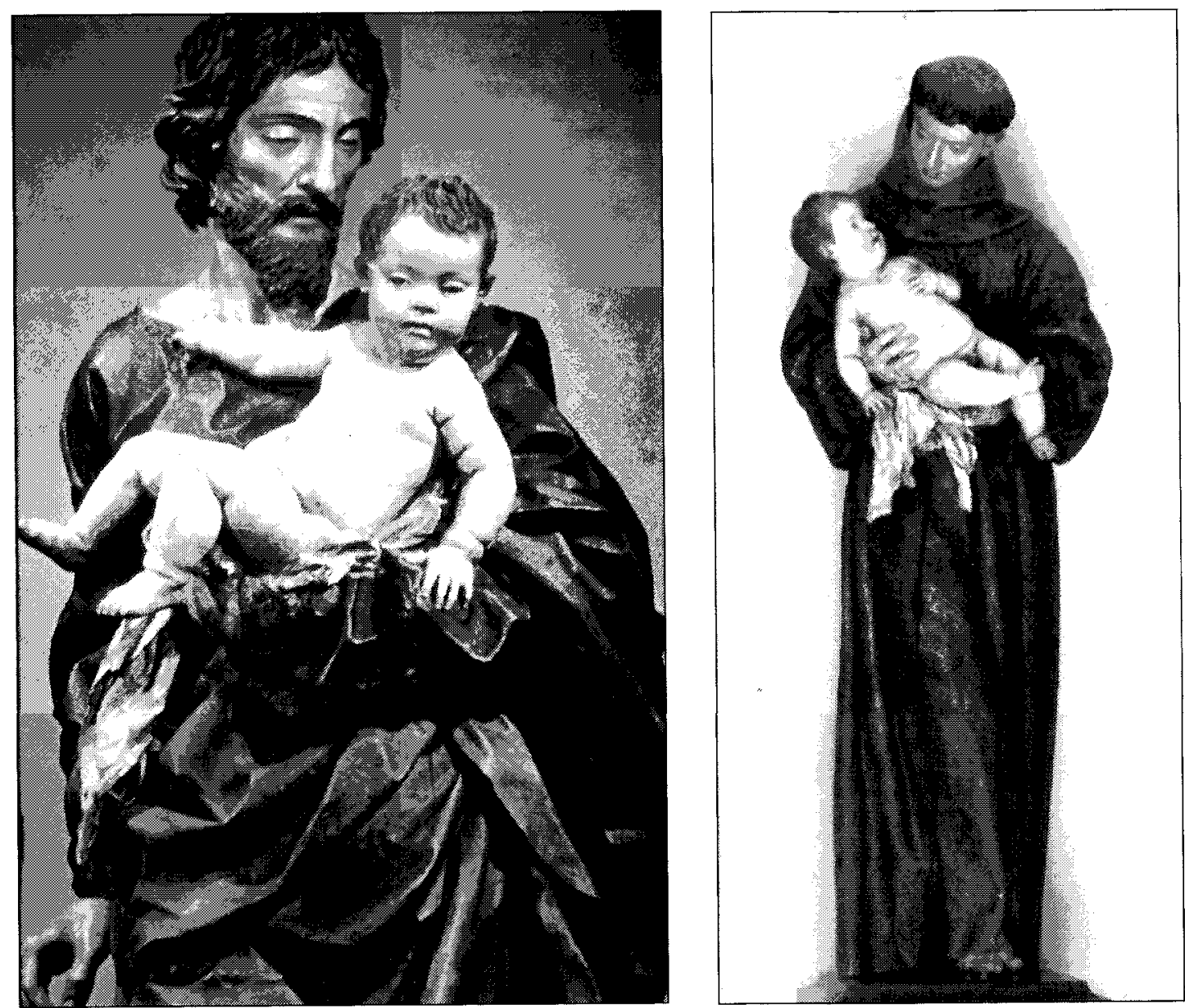

Fig. 33. San José con el Niño. Museo de Bellas Artes. Granada (detalle).

Fig. 34. San Antonio con el Niño. Museo de Bellas Artes. Granada.

\section{PROPUESTA DE RELACION DE OBRAS PARA EL CATALOGO DE ESCULTURAS DE ALONSO CANO}

Sevilla

1. Santa Teresa (repintada).

2. Inmaculada de Nervión.(incompleta)

3. Inmaculada de S. Julián (repintada).

4. Inmaculada de S. Andrés.

5. Inmaculada del retablo de la Campana (1629-32) (muy rehecha y repintada; muy desfigurada).

\section{Lebrija}

6. San Pedro. Retablo.

7. San Pablo. Retablo.

8. Virgen de la Oliva.

9. Evangelista San Mateo. (con intervención de taller y muy rehechas y transformadas posiblemente en la época de la hornacina, s. xvilI). 
10. Evangelista San Marcos.

11. Evangelista San Lucas.

12. Evangelista San Juan.

13. San Juan Bautista. Museo N. de Escultura de Valladolid.

\section{Madrid}

14. Crucificado de Lecaroz (muy repintado).

15. Nazareno Niño. San Fermín de los Navarros.

\section{Granada}

16. Inmaculada para el facistol. Sacristía de la Catedral.

17. Virgen de Belén. Museo de la Catedral.

18. San Diego de Alcalá. Instituto Gómez-Moreno.

19. Santa Clara. Convento de la Encarnación.

20. San Antonio. Iglesia de San Nicolás, Murcia.

21. San Antonio. Instituto Gómez-Moreno.

22. Niño Jesús bendiciendo. Málaga, colección particular.

23. San Pablo (busto). Museo de la Catedral.

24. San Juan de Dios (cabeza). Museo de Bellas Artes.

25. Santo Angel de la Guarda (mármol), con la colaboración de Mora. Convento del Ángel.

26. Adán (busto). Catedral.

27. Eva (busto). Catedral.

28. San José, con la ayuda de P. de Mena (sacado de puntos de modelos del maestro, manos y Niño Jesús son suyos)

29. San Antonio, con la ayuda de P. de Mena.

30. San Diego de Alcalá, con la ayuda de P. de Mena.

31. San Juan de Dios (formato pequeño para vestir). Refleja su estilo; pérdida de la policromía. Colección particular granadina.

- Los ángeles y cabezas de querubines de los retablos de Lebrija y de Santa Paula, fueron tallados en su taller según sus modelos y corregidos y tocados por él.

- Reproducidos mediante moldes de sus originales:

- San Jerónimo (en barro). Monasterio de San Jerónimo. Se conocen varios ejemplares en colecciones particulares.

- Niño Jesús (en plomo). Museo N. de Escultura de Valladolid, con ciertas relaciones estilísticas con el Niño de la Virgen de Lebrija. El resto de la figura resulta un tanto anodina e inferior. 